Revue d'histoire de l'Amérique française

AG REVUE D.HISTOIRE DE L'AMÉRIQUE FRANÇAISE

\title{
Problématique pour une nouvelle approche de la Constitution de 1791
}

\section{Pierre Tousignant}

Volume 27, numéro 2, septembre 1973

URI : https://id.erudit.org/iderudit/303264ar

DOI : https://doi.org/10.7202/303264ar

Aller au sommaire du numéro

Éditeur(s)

Institut d'histoire de l'Amérique française

ISSN

0035-2357 (imprimé)

1492-1383 (numérique)

Découvrir la revue

Citer cet article

Tousignant, P. (1973). Problématique pour une nouvelle approche de la

Constitution de 1791. Revue d'histoire de l'Amérique française, 27(2), 181-234.

https://doi.org/10.7202/303264ar d'utilisation que vous pouvez consulter en ligne.

https://apropos.erudit.org/fr/usagers/politique-dutilisation/ 


\title{
PROBLEMATIQUE POUR UNE NOUVELLE APPROCHE DE LA CONSTITUTION DE 1791
}

\author{
Pierre Tousignant \\ Département d'histoire \\ Université de Montréal
}

"L'histoire se fait avec la structure du passé"

Lors de la réunion annuelle de la Société historique du Canada tenue à Winnipeg en juin 1970, dans son discours présidentiel, l'historien Fernand Ouellet présenta un "bilan des acquis en histoire sociale du Bas-Canada" qui lui servit à dégager d'intéressantes "perspectives de recherches". ${ }^{1}$ Après avoir rappelé la place prépondérante qu'occupa l'histoire politique dans l'historiographie canadienne-française, il juge "capital d'envisager l'évolution des formes constitutionnelles et politiques dans leurs rapports avec l'évolution de la société". Tout en reconnaissant une certaine importance aux sentiments de francophilie ou de francophobie manifestés par les différents gouverneurs, il considère encore "plus fondamental de pénétrer leur vision de l'ordre politico-social". ${ }^{2}$ C'est précisément en fonction de ces préoccupations jugées "capitales" et "fondamentales" que j'avais orienté, déjà depuis plusieurs années, mes propres recherches en vue de la soutenance d'une thèse de doctorat intitulée $L a$ genèse et l'avènement de la Constitution de $1791 .^{3}$

Cette convergence de vues avec un historien bien connu valait d'être signalée pour engager le lecteur à suivre le fil conducteur de mes recherches. La présente étude ne constitue pas un résumé de thèse, mais plutôt l'exposé d'une démarche guidée par une problématique qui a la prétention de situer dans une nouvelle perspective l'instauration du régime parlementaire au Bas-Canada. Ce travail s'adresse tout particulièrement à ceux qui, s'étant déjà formé une opinion sur ce sujet, accep-

${ }^{1}$ Le texte de cette communication a été publié dans le Rapport annuel (1970) de la Société historique du Canada, 1 à 18.

2 Ibid., 13-14.

3 Cette thèse de Ph.D. (histoire) fut déposée à la Faculté des lettres de l'Université de Montréal, à l'automne 1971. On pourra la consulter à la bibliothèque de cette institution.

RHAF, vol. 27, no 2 (septembre 1973) 
teraient de mûrir de leur réflexion critique cet article qui comprend trois parties bien distinctes: la première traitera des ambitions et des frustrations de la bourgeoisie coloniale angloécossaise ; la seconde étudiera la conception des dirigeants britanniques de l'ordre politico-social en rapport avec la structure de la société métropolitaine; et la troisième montrera dans quelle mesure la Constitution de 1791 répondait aux objectifs de la politique impériale dans le cadre du "Old Colonial System".

Il apparaît d'abord important de faire quelques mises au point pour éviter toute méprise et dissiper tout malentendu. Précisons que c'est du côté métropolitain que se portera notre attention puisque nous sommes à une époque où, dans le cadre de l'empire britannique, en théorie comme en pratique, prédominait encore le "Old Colonial System" qui régissait les rapports et les liens de dépendance économique et politique des colonies à la métropole londonienne. Tout changement d'ordre constitutionnel relevait donc de la Couronne et de son Parlement. ${ }^{4}$ Dans le cas particulier qui nous intéresse, il s'agit d'une législation qui fut préparée sous forme de projet de loi par l'administration de William Pitt le Jeune et qui fut soumise à l'approbation du Parlement avant de recevoir la sanction royale. En conséquence, on ne saurait saisir le sens et la portée de cette législation impériale sans "pénétrer la vision de l'ordre politico-social" de ceux qui, directement ou indirectement, ont contribué à son élaboration.

Il nous faut aussi tenir compte du mode de fonctionnement du système de monarchie parlementaire sous le règne de George III puisque, comme nous le verrons, la Constitution de 1791 visait à appliquer au Bas-Canada le modèle constitutionnel métropolitain. Pour ce faire, il nous paraît capital de ne pas dissocier cette forme politique de gouvernement de l'état d'évolution des forces socio-économiques et des rapports de production dans une Angleterre où la structure politico-sociale, avant sa transformation par le processus de la révolution industrielle, présentait l'image d'une société aristocratique d'Ancien Régime. C'est en définitive l'étude de la société anglaise elle-même, telle qu'elle apparaît en cette seconde moitié du dix-huitième siècle, qui nous fait le mieux comprendre les objectifs politiques de ceux

${ }^{4}$ Notons qu'il fallut attendre le développement d'une grave crise révolutionnaire au sein de l'empire britannique avant que n'intervienne le Parlement pour modifier le régime constitutionnel des colonies. A ce point de vue, le Massachusetts Government Act et le Quebec Act constituaient des précédents dans l'histoire d'un empire administré en vertu de chartes coloniales relevant directement de la Couronne. 
qui décidèrent de l'instauration d'un régime parlementaire au Bas-Canada. ${ }^{5}$ Ainsi serons-nous en mesure d'apporter une réponse à la grande question que soulevait l'historien A. L. Burt en conclusion de son ouvrage devenu classique: Pourquoi, en 1791, les autorités métropolitaines sacrifièrent-elles les intérêts de la minorité protestante du Québec "on the altar of French Canada" ? 6

$$
\text { - I - }
$$

La minorité protestante du Bas-Canada en 1791 comprenait environ 10,000 "Old British Subjects" comparativement aux 150,000 "nouveaux sujets" catholiques. Concentrée dans les villes de Québec et de Montréal, cette minorité essentiellement bourgeoise tirait sa force et son dynamisme de son esprit d'entreprise capitaliste qu'elle sut mettre à profit grâce à sa situation privilégiée dans un pays conquis. Venus s'établir dans la vallée du Saint-Laurent à la suite des armées de conquête, les marchands anglo-écossais n'avaient pas tardé à s'imposer comme groupe social dominant. Ayant réussi à monopoliser la traite des fourrures, principale source d'enrichissement de la colonie, ces bourgeois conquérants étaient devenus, moins de trente ans après la cession du Canada à l'Angleterre, "les maîtres, sans concurrence, du commerce colonial". 7 Ils purent facilement démontrer au premier ministre Pitt, avec statistiques à l'appui, que "the whole trade of the province [of Quebec] is in the hands of, and depends on, the Old Subjects".8

5 Nous reconnaissons qu'il serait plus conforme au langage de science politique de dire que la Constitution de 1791 "posait seulement les bases institutionnelles du développement éventuel d'un régime parlementaire". Henri Brun, La formation des institutions parlementaires québecoises, 1791-1838 (Québec, PUL, 1970), 99-100.

6 The Old Province of Quebec (Toronto, 1933), 495. Depuis la parution de cet ouvrage, nous n'avons trouvé aucune réponse satisfaisante dans tous les écrits d'historiens du Canada que nous avons consultés. Pour expliquer pourquoi, finalement, les dirigeants britanniques permirent aux Canadiens francais d'avoir leur "national forum", nous ne pouvons évidemment pas considérer comme raisons fondamentales "the generally humane and tolerant principles" qu'à bon droit Hilda Neatby attribue aux autorités métropolitaines et aux administrateurs coloniaux. Voir la conclusion de son ouvrage, intitulé Quebec: The Revolutionary Age, 1760-1791 (Toronto, 1966).

7 C'est ce qu'affirmait Philippe de Rocheblave dans le discours qu'il prononça à l'Assemblée législative du Bas-Canada, le 21 janvier 1793.

8 Voir le Mémoire des marchands britanniques que leur délégué à Londres, Adam Lymburner, présenta au premier ministre William Pitt, en janvier 1788. Public Record Office (PRO), 30/8, 346: 124-127. 
Mais si prépondérante fût-elle économiquement, cette bourgeoisie coloniale qui regroupait les fils de la mère patrie ne put cependant pas réussir à faire prévaloir ses vues auprès des autorités métropolitaines lorsque vint le moment de diviser la province de Québec et d'établir une Chambre d'Assemblée au profit de la majorité de la population du Bas-Canada. Il y avait déjà près de trente ans que la minorité protestante réclamait ses droits et privilèges de sujets britanniques, et voici que sur le point de les obtenir, elle dut se résigner à sacrifier ses intérêts les plus chers sous le coup d'un double partage qui força les "Old British Subjects" du Bas-Canada à se retrancher derrière un conservatisme politique qu'ils n'abandonnèrent qu'après l'Union de 1840. En plus de les séparer de leurs compatriotes loyalistes du Haut-Canada, la Constitution de 1791 les obligea à partager le pouvoir législatif avec des sujets conquis.

$\mathrm{Au}$ lendemain du traité de Paris de 1763, les marchands britanniques s'attendaient à obtenir une Chambre d'Assemblée composée exclusivement d'éléments protestants et à la veille de l'Acte de Québec, ils justifièrent leur demande en faisant valoir auprès des autorités métropolitaines qu'en plus de contrôler les échanges commerciaux de la colonie, ils possédaient une part importante de la richesse immobilière, compte tenu de leur nombre. ${ }^{9}$ Mais le moment était mal choisi pour réclamer les droits et privilèges de sujets britanniques alors que les dirigeants de l'empire étaient aux prises avec une grave crise révolutionnaire en Amérique du Nord. Face à l'agitation et à l'insubordination des assemblées coloniales américaines, l'administration de Lord North n'eut pas de difficulté à faire endosser par le Parlement une constitution provinciale qui privait la minorité protestante de la jouissance des "libertés anglaises". Et à ceux qui, tel Edmund Burke, s'apitoyèrent sur le sort de ces quelques milliers de "Old British Subjects", le solliciteur général Alexander Wedderburn ne se fit pas scrupule de déclarer: ${ }^{10}$

${ }^{\boldsymbol{\theta}}$ Voir le Mémoire que les marchands britanniques du district de Québec adressèrent à Lord Darmouth, secrétaire d'Etat pour les colonies américaines, le 31 décembre 1773. A. Shortt et A. G. Doughty, ed., Documents relating to the Constitutional History of Canada, 1759-1791 (2 vol., Ottawa, 1918), I: 500.

10 Sir Henry Cavendish, Debates of the House of Commons in the Year 1774 for making more Effectual Provision for the Government of the Province of Quebec (Londres 1839), 57-58. L'émigration de GrandeBretagne vers les colonies américaines était alors percue comme un appauvrissement des ressources humaines du royaume: "It is universally admitted, écrivait un publiciste, that the real strength of a kingdom consists in the number of its inhabitants, and that its riches will be in proportion of the industry of its people." John Anderson, The Interest of Great Britain with Regard to Her American Colonies (Londres, 1782). 
A great deal has been said with regard to the British subjects settled in Canada. Now, I confess, that the situation of the British settler is not the principal object of my attention. I do not wish to see Canada draw from this country any considerable number of her inhabitants. I think there ought to be no temptation held out to the subjects of England to quit their native soil, to increase colonies at the expense of this country.

If persons have gone thither in the course of trade, they have gone without any intention of making it their permanent residence; and, in that case, it is no more a hardship to tell them, "this is the law of the land", than it would be to say so to a man whose affairs induced him to establish himself in Guernsey, or in any other part of North America.

Telle était la considération qu'un porte-parole officiel de l'administration gouvernementale pouvait porter à l'égard de ces "Adventurers in Trade" qui étaient venus au Québec "to mend their Fortune... and have been mostly left [there] by Accident". 11

Les débats parlementaires que suscita le "Quebec Bill", en plus de révéler les objectifs politiques des autorités métropolitaines, dans une conjoncture de crise au sein de l'empire où il importait avant tout de s'assurer le ferme attachement des anciens colons de la Nouvelle-France, démontrent clairement que l'institution d'une Chambre d'Assemblée paraissait inconcevable sans la participation des Canadiens qui formaient la très grande majorité des propriétaires terriens. Face aux critiques de l'opposition qui s'élevèrent contre le danger d'un gouvernement colonial non représentatif laissant à la discrétion du gouverneur l'exercice d'un pouvoir "arbitraire et despotique", le premier ministre North et le solliciteur général Wedderburn insistèrent sur le caractère "essentiellement provisoire" du régime de 1774. ${ }^{2}$ "As soon as the Canadians shall be in a condition to receive an assembly, déclara Lord North, it will be right they should have one. They will naturally wish to get the government into their own hands... [But] I do not think it would be wise, at present, to give them an assembly." 13 Alexander Wedderburn

${ }^{11}$ Selon le gouverneur Carleton, dans une lettre adressée au secrétaire d'Etat Shelburne, le 25 novembre 1767. Shortt et Doughty, ed., op. cit., I: 284 .

12 Sir Henry Cavendish, Debates in the House of Commons in the Year $1774 \ldots, 57$ et 290 .

13 Ibid., 290. 
en avait déjà précisé les raisons qu'endossèrent ses collègues du cabinet: ${ }^{14}$

To admit the Canadian to a place in that Assembly ... would be a dangerous experiment with new subjects, who should be taught to obey as well as to love this country, and, if possible, to cherish their dependence upon it. Besides, it would be an exhaustible source of dissension and opposition between them, and the British subjects. It would be no less difficult to define the persons who should have a right to elect the Assembly. To exclude the Canadian subject would be impossible, for an Assembly chosen only by the British Inhabitants, could no more be called a representative body of that colony, than a council of state is.

D'autre part, il fallait tenir compte du clivage social hérité de la colonisation française dans le cadre du système seigneurial:

To admit every Canadian proprietor of land would be disgusting and injurious to all the men of condition in the Province, who are accustomed to feel a very considerable difference between the seignior and the censier [censitaire], though both are alike proprietors of land. Nor would it be beneficial to men of inferior rank; for every mode of raising them to the level of their superiors, except by the efforts of their own industry, is pernicious. It seems, therefore, totally inexpedient at present to form an Assembly...

Fort de l'assurance donnée par le gouverneur Carleton que le maintien du système seigneurial garantissait une parfaite subordination "from the first to the lowest", 15 le conquérant avait intérêt à ne pas confondre les seigneurs avec leurs censitaires dans un même corps législatif. Les membres de la petite noblesse seigneuriale - "the better sort of Canadians" - méritaient dans une Crown Colony l'honneur d'être nommés conseillers du gouverneur à l'instar des Lords que le roi choisissait pour faire partie de son Privy Council.

L'Acte de Québec, en autorisant des sujets catholiques à siéger au Conseil législatif, 16 obligea la minorité protestante à réviser ses positions. Au lendemain de la guerre d'Indépendance des Etats-Unis, les marchands britanniques acceptèrent de se

14 "Report of Solicitor General Alexander Wedderburn" (6 décembre 1772). Shortt et Doughty, ed., op. cit., I: 426. Ce rapport servit à la préparation du projet de loi de 1774 .

15 Lettre au secrétaire d'Etat Shelburne, le 24 décembre 1767. Shortt et Doughty, ed., op cit., I: 289.

16 Seuls, parmi les Canadiens, les membres de la classe seigneuriale furent appelés à siéger au Conseil législatif. 
lier au mouvement réformiste canadien qui recrutait ses chefs dans les rangs de la petite et moyenne bourgeoisie groupant des commerçants et des boutiquiers aussi bien que des notaires et des avocats. ${ }^{17}$ Conformément aux désirs de ces réformistes, ils préparèrent conjointement la fameuse pétition du mois de novembre 1784 demandant que "la Chambre des représentants du peuple soit indistinctement composée d'anciens et de nouveaux sujets... librement élus par les habitants des villes et des campagnes ou paroisses de la province". ${ }^{18}$ C'était un engagement fort risqué et un risque fort mal calculé. Ils escomptaient pouvoir, grâce à leur ascendant économique et aux faveurs anticipées de la métropole, imposer leurs vues au sein de la future assemblée législative et ajoutons qu'au moment de leur alliance avec les réformistes canadiens, ils ignoraient que l'administration de William Pitt se préparait à diviser les forces britanniques par la création de deux provinces sœurs. Ils furent doublement déjoués dans leurs calculs: d'une part, ils sous-estimèrent la volonté de contrôle du pouvoir législatif par les représentants de la majorité - volonté clairement exprimée au cours des années qui précédèrent l'avènement du régime parlementaire; ${ }^{19}$ d'autre part, ils s'abusèrent grandement en croyant que l'administration métropolitaine, non encore remise du choc de la Révolution américaine menée par la bourgeoisie coloniale de Boston, allait favoriser une forte représentation des villes de Québec et de Montréal à la Chambre d'Assemblée du Bas-Canada.

Quelques esprits anglo-saxons clairvoyants n'étaient pas sans appréhender l'établissement d'une Chambre d'Assemblée "indistinctement composée d'anciens et de nouveaux sujets". Qu'adviendrait-il, se demandait le conseiller législatif Hugh Finlay, "if the Canadian freeholders send only Canadian representatives"? Pouvait-on s'en remettre à la masse de la population, en grande majorité rurale, pour élire des représentants

${ }_{17} \mathrm{Au}$ sujet de cette alliance des forces bourgeoises, voir Pierre Tousignant, La genèse et l'avènement de la Constitution de 1791, chapitre VI.

18 Pour la version française originale de cette pétition adressée au roi et "aux deux Chambres du Parlement", voir APC, C.0. 42, 47, f. 187190. On trouvera dans Pierre Tousignant, op. cit., Appendice A, 447-459, la liste complète des quelque 1,500 signataires canadiens-français. Ignorant l'existence de ce mouvement réformiste canadien, les archivistes Shortt et Doughty (op. cit., II: 742-752) n'ont publié que la liste des quelque 850 pétitionnaires anglo-écossais.

19 Pierre Tousignant, "Les Canadiens et la réforme constitutionnelle, 1783-1791", communication présentée lors de la réunion annuelle de la Société historique du Canada, à l'Université McGill (Montréal), en juin 1972. Voir également, idem, La genèse et l'avènement de la Constitution de 1791, chapitre VI. 
qui défendraient les intérêts économiques de la minorité protestante ? Ne serait-il pas plus prudent d'instruire ce "peuple ignorant" et de faire des Canadiens de bons Englishmen avant de se lancer dans pareille aventure ? ${ }^{20}$ Et dans une autre lettre adressée à l'un de ses confidents, Finlay déplorait la naïveté de ses compatriotes: ${ }^{21}$

A House of Assembly composed of the New Subjects (perhaps led in their deliberations by the Clergy) would be ill fitted to make good laws for a Commercial Country. I know that the Old Subjects flatter themselves that English Merchants will be returned to represent the Towns, and that they would have influence enough to carry whatever wholesome laws they might propose, but that is far from being a clear case: every tax would meet strong opposition.

Un citoyen de Montréal jugea nécessaire de servir un avertissement public à ses compatriotes en les mettant en garde contre un tel projet: "The idea of a House of Assembly, pouvait-on lire dans la Montreal Gazette du 14 décembre 1786, being introduced into this Province for the better government of its Inhabitants ... appears to me unavailing, impolitic and chimerical". Et développant sa pensée, il précisa ses motifs d'inquiétude:

His Majesty's Old Subjects, allowing they obtain an equal representation, would not at any time have a Majority in the House, for these reasons: the principal Landholders consisting of New Subjects and the chief interest being lodged in them, and their Seigneurs, of which the Clergy composing the Majority, would maintain an influence, and be productive of Jealousies, Discord, and Discontent.

C'était faire preuve de lucidité que d'appréhender les irréductibles conflits qui surgiraient au sein d'une arène politique où seraient confrontés des intérêts aussi opposés que ceux de la bourgeoisie urbaine anglo-écossaise et ceux du monde rural canadien-français.

La perspective d'une Chambre d'Assemblée dominée numériquement par les représentants de la majorité des propriétaires terriens de la province alarma le procureur général James Monk qui avait bien perçu la détermination des chefs réformistes canadiens d'obtenir un pouvoir législatif pouvant donner au peuple

20 Voir ses deux lettres au sous-secrétaire d'Etat, Sir Evan Nepean, les 22 octobre et 6 novembre 1784. Shortt et Doughty, ed., op. cit., II: 739-740; APC, C.0. 42, 16: 213-214.

21 Lettre au colonel Philipp Skene, le 14 janvier 1785. APC, C.0. 42, 17: 203-204. 
conquis le contrôle de la taxation et, par ce moyen, celui des dépenses de l'administration provinciale. ${ }^{22}$ Inquiété d'autre part par l'acharnement des marchands anglo-écossais pour acquérir à tout prix leurs droits et privilèges de sujets britanniques, Monk alerta ses confidents londoniens en leur recommandant de conseiller Adam Lymburner qui avait été délégué à Londres pour plaider la cause de la bourgeoisie coloniale: ${ }^{23}$

His Mind seems to rest upon attaining the House of Assembly, and that on almost any Terms, and supposed it will work the Reform. He [Lymburner] counts highly upon the Influence of the Commercial Interest to get English returned into the House, \& hold a majority. I am satisfied he depends too much on that supposed Influence, and it is of too much importance, for a Legislator to depend on. A House of Assembly unlimitted in its power, unsecured to the Protestant Interest, the King's Old Subjects, would be a Real curse to the Colony and what Great Britain ought never to grant.

Il n'était évidemment pas question dans l'esprit des autorités britanniques de laisser à la future Assemblée législative du BasCanada (ni d'ailleurs à celle du Haut-Canada) le contrôle de la liste civile que craignait Sir James Monk. N'eût-il été concerné que par ce point de vue, Monk aurait pu dormir en paix car son salaire de futur juge et de conseiller exécutif ne devait pas tomber sous la coupe des représentants du peuple.

Dès que furent connus les termes du projet de nouvelle constitution canadienne, les marchands britanniques du Canada qui se trouvaient alors à Londres tentèrent un ultime effort, de concert avec leurs créanciers métropolitains, pour convaincre le Chancelier de l'Echiquier William Pitt de protéger leurs intérêts économiques par une réglementation fixant un code de lois commerciales qui échapperaient au contrôle de la législature provinciale; mais ce fut en vain comme le rapporta le quotidien londonien The Morning Chronicle dans son numéro du 14 mars 1791: ${ }^{24}$

Mr. Pitt did not see any inconveniencies to commerce from the intended arrangement. Whether the laws were French or

22 Voir à ce sujet la communication mentionnée supra, note 19.

23 Lettre à l'ex-procureur général Francis Masères, le 3 novembre 1788. APC., M.G. 23 (Monk Papers), G. II, 19, vol. 2: 75-83. Monk alerta également Sir Brook Watson, riche bourgeois londonien enrichi dans le commerce colonial et qui, en plus d'être Alderman, représentait la City à la House of Commons. Voir lettre datée du 25 octobre 1788, dans Ibid., 70 sqq.

24 Signalons qu'il s'agissait d'un journal d'opposition à l'administration gouvernementale. 
English, they would soon be equally understood by the inhabitants. Merchants were accustomed to different systems of law, as in every foreign Port to which they traded, they found a different system; and he could not yet satisfy them whether the proceedings and records of the Assembly and Courts, would be in English or French, or both.

They separated without being satisfied with each other, and the English Merchants have reason to dread which they have been complaining of for years - the uncertainty of the Canada Code, will not be done away by the establishment of an Assembly, which being necessarily composed of the French Landholders, who have little concern with the commerce of the Province, will support the Government by duties on imports rather than on produce - and which will always give them decided superiority over the English settlers.

Le secrétaire d'Etat W. W. Grenville, l'auteur du projet de loi de 1791, s'était déjà penché sur ce problème de codification des lois commerciales sans y apporter de solution satisfaisante. Conscient des préjudices que pourrait subir la bourgeoisie coloniale par l'établissement d'une Chambre d'Assemblée "in which the Landed, or Canadian Interest would probably preponderate", il ne considéra pas cependant que les inconvénients qui découleraient de cette situation étaient de nature à retarder l'adoption de ce qu'un historien a justement appelé le "Lord Grenville's Act". ${ }^{25}$ A défaut de la protection d'un code de lois commerciales anglaises, l'administration de William Pitt offrit en compensation aux colons britanniques du Québec la possibilité d'acquérir des terres selon le mode de tenure en franc et commun soccage en dehors de la zone seigneuriale. ${ }^{26}$ Ce fait à lui seul suffirait à illustrer que la Constitution de 1791 n'a pas été conçue en fonction des intérêts économiques d'une bourgeoisie commerçante. Ce fut la dure leçon que devait apprendre Adam Lymburner durant son séjour à Londres.

Ce délégué de la bourgeoisie coloniale eut la possibilité de se faire entendre devant le comité de la House of Commons lors des débats parlementaires sur le projet d'Acte constitutionnel. Le 23 mars 1791, il présenta un vigoureux et vibrant plaidoyer en faveur de la minorité protestante du Québec dont il compara le sort aux enfants d'Israël exilés en Egypte et à qui l'on deman-

25 Selon le titre même du deuxième chapitre de l'ouvrage de Helen Taft Manning, The Revolt of French Canada, 1800-1835 (Toronto, 1962). Il sera fait mention des sources documentaires dans la troisième partie de ce travail.

${ }^{26}$ Voir l'article XLIII de l'Acte constitutionnel. 
dait "to make Bricks without Straw". ${ }^{27}$ Il critiqua à fond la séparation du Bas et du Haut-Canada comme étant contraire à ce que la nature avait uni par la géographie et préjudiciable aux liens d'intérêts nationaux qui unissaient les fils de la mère patrie entre eux: ${ }^{28}$

The strong principle of Nationality or National Prejudice, which at present connects the People of the Province to one another, as being Members of one State, who though scattered over an immense country, yet all look up to one Center of Government for protection and relief, is of the utmost consequence for the security of Government, in a Country where the Inhabitants are so much dispersed.

N'y avait-il pas lieu de craindre que l'isolement des Loyalistes du Haut-Canada ne contribuât à affaiblir leur attachement à la Couronne britannique ? Une telle séparation ne serait-elle pas une cause de désunion entre les deux provinces qui nuirait au développement économique du Canada? "This Division, résumait Lymburner, appears to me dangerous in every point of view of the British Interest in America, and to the Safety, Tranquillity, and Prosperity of the Inhabitants of every part of the Province of Quebec." 29

En contre-proposition, Lymburner soumit un plan d'une seule et unique législature provinciale dotée d'un double système judiciaire pour assurer la protection des différentes lois de propriété. Ne serait-ce pas le moyen par excellence de favoriser l'assimilation graduelle des Canadiens français tout en respectant ce qui leur tenait à cœur tandis que, par la création de deux gouvernements provinciaux, les autorités britanniques faisaient obstacle à cette assimilation et obligeaient la minorité protestante à combattre "the prejudices and prepossessions of those of our fellow [Canadian] subjects, who being unacquainted with the nature, the principles, or circumstances of Mercantile and Personal Transactions, are little inclined to favour them" ? ${ }^{30}$

Lymburner s'en prit également au projet particulièrement cher au secrétaire d'Etat Grenville de constituer un corps aristocratique héréditaire avec les membres du Conseil législatif. Jugeant ce projet "absolutely ridiculous", il fit observer que le

27 Paper read at the Bar of the House of Commons, by Mr. Lymburner, 23.d March 1791. Imprimé par William Moore (Herald Printing Office, Quebec, 1791), $47 \mathrm{pp}$.

28 Ibid., 10-11.

29 Ibid., 14.

30 Ibid., 7 et 16. 
morcellement de la propriété foncière dans le cadre du système seigneurial rendait dérisoire ce qui, en Angleterre, grâce aux lois de primogéniture, "enables the Representatives of Noble Families to support the Dignity and Splendour of their Situations, and to live in that State of Independence which secures the proper Respect of their elevated Rank, as hereditary Peers of the Realm". ${ }^{31} \mathrm{Au}$ Canada, argumenta-t-il, la richesse et l'influence se trouvaient aux mains de la bourgeoisie commercante qui aspirait "naturellement" à contrôler le pouvoir législatif: ${ }^{32}$

\begin{abstract}
There are now, among the Mercantile Gentlemen in the Province, those whose moveable fortunes are perhaps equal, if not superior to any of the Seigneurial Estates; and who, from the Employment and Support they give to thousands of the People, have infinitely more influence in the Country than the Seigneurs... This Honourable House must perceive, from the very small value of the Landed Fortunes, that the only means of Accumulation in that Country must be by the operations of Trade and Commerce ... That it is more than probable in Twenty Years, nay, perhaps in Ten Years, a new set of men may come forward, who may acquired and realized fortunes much superior to any now in that Country; and who, it is natural to suppose, will possess a proportional degree of Political Power and Influence.
\end{abstract}

Lymburner ne cacha pas son insatisfaction quant aux modalités d'application du système de représentation prévues par l'administration métropolitaine. D'abord, il estima que le nombre des représentants (fixé à trente, selon le projet original) était nettement insuffisant pour bénéficier de tous les avantages d'une Chambre d'Assemblée - cette "glorieuse institution" du génie politique britannique. Dans la perspective d'un accroissement rapide de la population qui dépasserait vraisemblablement les 500,000 âmes d'ici une génération, il fallait au moins doubler le nombre des représentants pour "commander le respect et assurer la confiance du Peuple". ${ }^{33}$ En second lieu, le renouvellement de chaque Assemblée au scrutin populaire devrait être triennal et non septennal tel qu'on l'envisagea initialement. Enfin, ce qui n'était pas le moindre des soucis du délégué de la bourgeoisie coloniale, comment ne pas déplorer qu'en vertu du XIV ième article du projet de loi, l'administration de William Pitt laissait à la discrétion du gouverneur Dorchester la répartition

31 Ibid., 17-18.

32 Ibid., 19-20.

33 Ibid., 21-24. 
des districts et comtés électoraux ainsi que la détermination du nombre des représentants par comté et ville: ${ }^{\mathbf{3 4}}$

This is placing the whole Power in the Hands of the Governor; he is to divide the Province as he pleases, he is to order the Proportion of Representatives as he pleases, and he is to have the Power of naming whom he pleases to act as Returning Officer. The Freedom and Independence of the Legislature is an Object of the utmost Importance to every Country; and it has been one great Cause of the Complaint against the Quebec Act, that the Legislature was too much dependent on the Governor... The Distribution of the Representation is an Object of the greatest Importance to the Province, and ought to be settled in a certain Degree by this Honourable House ...

Le découpage de la carte électorale par celui que l'on a surnommé "the father of the Quebec Act",35 Sir Guy Carleton élevé à la pairie sous le nom de Lord Dorchester, n'avait rien en effet de rassurant pour les marchands britanniques du Canada et, à bon droit, Lymburner insista sur la nécessité de prévoir un certain équilibre entre la représentation urbaine et celle des comtés ruraux de la province. N'était-il pas dans l'intérêt de la GrandeBretagne, première nation commerçante du monde, de favoriser la représentation d'une bourgeoisie conquérante qui assurerait le mieux le développement économique et la prospérité de la colonie? "The Landed Interest, déclara-t-il, has always been too prevalent, and has, at Times greatly oppressed the Commerce and impeded the Operations of Government." 36

C'est en vain qu'Adam Lymburner tenta de sensibiliser les membres de la House of Commons au fait que le temps était venu de partager le pouvoir politique entre les détenteurs de la richesse mobilière et les possesseurs de la richesse foncière. La réalité socio-politique de la nation, telle que représentée par la composition du Parlement britannique, empêchait la reconnaissance d'un tel principe d'équilibre dans le rapport des forces économiques. Avant son retour à Québec, Lymburner fit une dernière démarche auprès du successeur de W. W. Grenville au secrétariat d'Etat, Henry Dundas, dans l'espoir de convaincre ce nouveau ministre d'intervenir en faveur de la bourgeoisie coloniale. Il lui présenta un plan de répartition prévoyant "that one half of 34 Ibid., 25.

35 Selon l'historien A. L. Burt, Guy Carleton, Lord Dorchester, 17241808. Brochure de la Société historique du Canada, no 5 (2ième édition, Ottawa, 1957), 5.

36 Suite du document mentionné supra, note 27. Ibid., 25-26. 
the number of Representatives to be elected shall be chosen by the Towns" et, à l'appui, soutint l'argumentation suivante: ${ }^{\mathrm{g}}$

The commercial Interest in Canada is entirely concentrated in the Towns of Quebec and Montreal and it is no more than fair that the commerce should have such a proportion of the Representation as will not only secure from oppression but as will hold out the prospect of protection and encouragement; it is only by its commerce that the Province can be valuable to Great Britain or that the Province can become prosperous and wealthy - the Landed Interest will of course have the greatest Influence in the Council - I therefore submit that Government in arranging the House of Assembly should not put it in the power of ignorant and obstinate men to carry into effect the absurd Idea that it is the Land holders Interest to oppress Commerce.

En adressant copie de ce plan au gouverneur Dorchester, le secrétaire d'Etat lui signifia très clairement: "His Majesty's servants entirely disapprove that arrangement". ${ }^{38}$ Ainsi les marchands anglo-écossais durent se satisfaire du cinquième de la représentation électorale pour les villes de Québec, Montréal et TroisRivières, soit dix circonscriptions sur un total de cinquante à l'étendue de la province; mais grâce à leur richesse et à leur influence, ils purent compter bon an, mal an, sur environ le tiers des sièges à l'Assemblée législative du Bas-Canada.

Si nous considérons l'accueil que réserva la métropole aux demandes de la bourgoisie coloniale de Québec et de Montréal, qui n'était ni en posture ni en mesure de refuser les offres des autorités britanniques comme le fit jadis celle de Boston, ne trouve-t-on pas le même fossé d'incompréhension qu'à l'époque de la Révolution américaine alors que les "King's Servants", depuis Westminster, décidaient des affaires de l'empire avec la mentalité de grands seigneurs féodaux. Ainsi en témoigne cet aveu d'un bon loyaliste du Massachusetts qui, après avoir trouvé refuge en Angleterre, notait dans son journal: "It piques my pride ... to hear us called 'our colonies, our plantations', in such terms and with such airs as if our property and persons were absolutely theirs, like the 'villains' and their cottages in the old feudal system, so long since abolished, though the spirit of leaven

37 Ce plan fut annexé à la lettre que le secrétaire d'Etat Dundas envoya au gouverneur Dorchester, le 16 septembre 1791. Douglas Brymner, Report on Canadian Archives, 1890 (Ottawa, 1891), 38-41.

38 Ibid., 39. 
is not totally gone, it seems." 39 Nous verrons que cette mentalité féodale était loin d'être complètement disparue au Parlement britannique.

$$
\text { - II - }
$$

Dans cette deuxième partie certaines affirmations pourront paraître contestables à ceux qui, sous l'influence de l'interprétation Whig de l'histoire, ont appris à projeter l'image d'une Angleterre victorienne libérale sur la société anglaise du dixhuitième siècle. ${ }^{40} \mathrm{Ce}$ danger d'anachronisme guette même les esprits vigilants et soucieux d'objectivité historique. Ainsi en est-il des historiens qui ont jugé et condamné la politique coloniale de l'administration du second Pitt sous l'éclairage du célèbre Rapport de Lord Durham. C'est faire abstraction des profondes transformations qui marquèrent toute la société anglaise au cours des cinquante années qui séparent la Constitution de 1791 de l'Acte d'Union de 1840 - transformations qui allaient permettre le passage du "First" au "Second British Empire", c'est-à-dire d'un empire régi par le "Old Colonial System" à un empire fondé sur le "Free Trade".

Deux générations seulement séparaient William Pitt le Jeune du gendre de Lord Grey qui prôna l'Union des deux Canadas; mais ces deux générations, plus qu'à toute autre époque antérieure, furent capitales, car c'est précisément durant ce demi-siècle que la révolution industrielle, en faisant apparaître

39 Extrait du journal de Samuel Curwen (1715-1802), le 18 décembre 1776. George A. Ward, ed., Journal and Letters of the late Samuel Curwen, judge of Admiralty...An American Refugee in England, from 1775 to 1784 (New York, 1842), 90.

40 A ce sujet, voir Herbert Butterfield, The Whig Interpretation of History (Londres, 1931). Cette interprétation du passé vu à travers le prisme de l'idéologie protestante et libérale de l'époque victorienne a profondément marqué l'historiographie anglo-saxonne jusqu'à la dernière Grande Guerre. Les défenseurs de la tradition Whig font remonter l'avènement des libertés démocratiques à la Révolution glorieuse de 1688 qu'ils considèrent avoir été la plus libérale des révolutions dans l'histoire de l'humanité et avoir servi de modèle et de phare dans l'évolution constitutionnelle du monde occidental. Parmi ses plus illustres représentants en Grande-Bretagne, mentionnons Sir Thomas Erskine May (1815-1886), Lord Acton (1834-1902), George Otto Trevelyan et son fils, George Macaulay Trevelyan (1876-1962). Au Canada anglais, dans ce courant d'interprétation Whig, nous trouvons, entre autres historiens, William Kingsford, Wm P. M. Kennedy et Edgar McInnis. C'est ainsi que ce dernier voit dans la constitution de 1791 "a direct effort to attach the mass of the population by a free and generous gift of self-government". Canada: A Political and Social History (2e édition, New York, 1959), 170. 
de nouveaux modes et rapports de production, ébranla tout l'édifice de l'ancienne structure sociale héritée d'un monde rural où le pouvoir politique était l'apanage d'une élite aristocratique dont la principale richesse provenait de la terre. Sous la pression de nouvelles forces socio-économiques engendrées par une révolution qui donna naissance à une bourgeoisie industrielle, la réforme électorale de 1832 rendit possible, en portant un premier coup à l'élite traditionnelle, l'accès au pouvoir politique des représentants d'une "middle class" en ascension. Etant réceptif aux nouvelles valeurs bourgeoises véhiculées par cette classe montante, Durham qu'on a surnommé le "Radical Jack" ne pouvait avoir la même vision de l'ordre politico-social que le fils de l'artisan de la Conquête qui avait reçu sa formation dans une Angleterre où prédominait encore le système de valeurs d'une société d'Ancien Régime. En forçant quelque peu la comparaison, l'on pourrait dire qu'entre le conservatisme du second Pitt et le libéralisme de Lord Durham, il y avait autant de différence qu'entre les préoccupations de Sir William Blackstone en rédigeant ses Commentaries on the Laws of England (1765-69) et celles de John Stuart Mill en publiant ses Considerations on Representative Government (1861).

A l'avènement du règne de George III en 1760 , l'infra-structure économique de la société anglaise ne se distinguait pas fondamentalement de celle qu'on retrouvait tant en Europe continentale que dans tout le monde occidental qui formait alors un vaste domaine rural où la vie agricole et la production de la terre dominaient l'ensemble de l'économie. Ce fait fondamental permet de comprendre que la propriété foncière constituait la base même de l'organisation socio-économique de l'Angleterre, à l'aube de la révolution industrielle. Ainsi a-t-on pu affirmer: "Landed property was the foundation of the eighteenth-century society." 41

Pour caractériser le mode d'organisation socio-économique des sociétés pré-industrielles d'Ancien Régime, nous n'hésitons pas à utiliser le terme "féodal" au sens que lui ont donné les historiens réunis à Toulouse à l'automne 1968, lors d'un colloque international où ils adoptèrent à l'unanimité la définition suivante de la féodalité: "Un système économique et social caractérisé par le prélèvement d'une partie du revenu des exploitants du sol par une aristocratie principalement foncière jouissant de

41 G. E. Mingay, English Landed Society in the Eighteenth Century (Londres, 1963), 3. 
privilèges politiques et de droit de justice." 42 Même s'il n'y avait pas en Angleterre de cadre juridique de référence pour déterminer l'appartenance des individus ou des groupes sociaux à des "ordres" bien définis, tels qu'ils existaient en France, on n'en trouve pas moins d'un côté et d'autre de la Manche des sociétés de structure aristocratique. Si la nobility de la House of Lords ne jouissait pas des privilèges exclusifs qui distinguaient et séparaient socialement la noblesse française, elle n'en était pas moins issue de l'aristocratie foncière qui, en majeure partie, constituait l'élite dirigeante. En fait, précise l'historien $H$. J. Habakkuk: "In England political power and social standing depended to a greater extent than elsewhere of the ownership of landed property as opposed to lineage or royal favour." ${ }^{43}$ S'il n'y avait pas de lien seigneurial attaché à la terre, comme en France, la terre n'en représentait pas moins la valeur par excellence, la somme de toutes les valeurs: "Wealth, power and social influence produced by ownership of land enabled the landowning classes to control all local government beyond the bounds of larger towns and to secure a dominating representation in Parliament." ${ }^{44}$ Dans ces conditions, il n'y a pas lieu de s'étonner de trouver chez les dirigeants britanniques une mentalité que nous qualifions de "féodale", entendant par là la mentalité de ceux qui liaient le pouvoir et le prestige à la possession de la terre et qui attribuaient à la propriété foncière la marque distinctive du statut social.

Dans cette société anglaise issue de la Révolution glorieuse de 1688, tout bon disciple de Locke, qu'il fût Whig ou Tory, considérait, à l'instar de James Harrington, "that a certain degree of power is made to follow a certain degree of property as the true foundation of all free and well-contrived governments".45 Daniel Defoe, tout en se faisant l'apologiste des valeurs bourgeoises, n'en partageait pas moins cette conviction chère aux hommes de son temps: "I make no question but property of land

42 Actes du colloque international du CNRS, L'abolition de la féodalité dans le monde occidental, Toulouse, 12-16 novembre 1968 (2 vol., Paris, 1971), II: 885-886. Au sens restreint du droit (sens juridique), le terme "féodal" s'applique aux institutions héritées du Moyen Age et caractérisées par le lien seigneurial attaché à la terre. Les historiens d'allégeance marxiste définissent la féodalité comme un mode de production historique fondé sur la propriété foncière.

43 Etude intitulée "England", dans A. Goodwin, ed., The European Nobility in the Eighteenth Century '(Londres, 1953), 15 .'

${ }_{44}$ G. E. Mingay, op. cit., 3.

45 Rapporté par Francis Masères à l'appui de son "Plan of a General Assembly of the Freeholders of the Province of Quebec" (1768), in Things to be settled in the Province of Quebec (Londres, 1772). 
is the best title to government in the world." ${ }^{46}$ Le non moins célèbre Jonathan Swift proclamait: "Law in a free country is, or ought to be, the determination of the majority of those who have property in land." 47 Cinquante ans plus tard, en formulant son credo libéral, Adam Smith reconnaissait que l'organisation de la société politique avait pour fondement la protection du droit de propriété: "Civil government, so far as it is instituted for the security of property, is in reality instituted for the defence of the rich against the poor, or of those who have property against those who have none at all." 48 Il n'est donc pas surprenant que la langue anglaise du dix-huitième siècle ait si étroitement associé, au point d'en faire des synonymes, les mots liberty et property.

Prétendre que la Révolution glorieuse de 1688 fut l'aboutissement d'une "révolution bourgeoise" ayant rendu possible "un compromis social et politique qui associa au pouvoir bourgeoisie et aristocratie",49 c'est entretenir une grande confusion sur le rôle que joua dans l'organisation politique la gent commerçante et financière et la place qu'elle occupa dans l'administration gouvernementale au cours du dix-huitième siècle. Pour clarifier cette question, voyons ce qu'en pense J. H. Plumb, grand spécialiste de l'administration de Walpole. Bon gré, mal gré, nous apprend-il, les représentants des milieux d'affaires se plièrent aux règles du jeu aristocratique que leur imposa l'oligarchie Whig sous les règnes des rois George $\mathrm{I}^{\text {er }}$ et George II : ${ }^{50}$

The Whig party fused the interests of aristocracy, high finance, and executive government, a process extended by Walpole to embrace the bulk of the landed gentry. By doing so he put the noblemen and gentlemen back at the heart of English political society. This was to be of tremendous importance for England's future development. The seventeenth century had witnessed the beginnings and partial success of a bourgeois revolution that came near to changing the insti-

46 Cite par Sir Lewis Namier, England in the Age of the American Revolution (2ième édition, Londres, 1961), 19.

47 Ibid., 19.

48 The Wealth of Nations (1776), livre V : premier chapitre.

49 Albert Soboul, "La Révolution française dans l'histoire du monde contemporain: étude comparative", L'Information historique, $39^{\epsilon}$ année, $n^{\circ} 3$ (1969): 113 . Tout aussi vague et imprécise cette autre affirmation de l'historien Soboul: "l'argent était finalement le principal critère de distinction sociale" (Ibid., 113).

50 The Growth of Political Stability in England, 1675-1725 (Londres, 1967). Editions "Penguin Books" (1969), 186-187. Cet ouvrage comprend la série de conférences que le professeur Plumb présenta dans le cadre des "Ford Lectures", à l'Université d'Oxford, en 1965. 
tutions of government. In this, however, it never succeeded. The Revolution of 1688 and all that followed were retrogressive from the point of view of the emergence of the middle class into political power. Socially and economically they continued to thrive, but not politically. The power of the land and of commerce fused to create a paradise for gentlemen, for the aristocracy of birth; it thus became much easier for England to adopt an imperial authority, to rule alien peoples, and to train its ruling class for that purpose, rather than to ajust its institutions and its social system to the needs of an industrial system.

A cette mise au point, ajoutons celle de l'historien H. J. Habakkuk qui précise comment l'Angleterre hanovrienne devint "a paradise for gentlemen": ${ }^{51}$

Dans l'Angleterre du XVIII' siècle, l'influence sociale et politique dépendait bien plus directement de la propriété terrienne qu'avant 1688 . Aux $\mathrm{XVI}^{\mathrm{e}}$ et $\mathrm{XVII}^{\mathrm{e}}$ siècles, la faveur royale était une source importante du pouvoir politique; au XVI siècle, la Couronne fut en mesure de doter plusieurs "hommes nouveaux" de domaines provenant des terres confisquées aux monastères. En pareils cas, l'influence politique venait d'abord

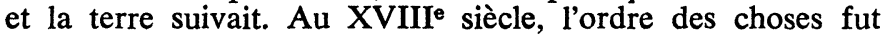
renversé. La possession de la terre devint une condition de l'exercice soutenu du pouvoir politique.

Cette condition d'accès au pouvoir politique, à une époque où le Parlement britannique représentait "le sol plus que la population", 52 permet de comprendre pourquoi les membres de la bourgeoisie devaient acquérir de la richesse immobilière pour se faire élire et accéder aux postes de l'administration gouvernementale: "Wealth amassed in trade was laid out in landed estates and used to secure seats in the House of Commons, for both helped to lift their holders into a higher social sphere." 53

A l'avènement du règne de George III, le Parlement était devenu la chasse gardée d'une oligarchie aristocratique compre-

51 "La disparition du paysan anglais", ANNALES, Economies, Sociétés, Civilisations, XX, no 4 (1965): 661. Il s'agit d'une traduction pour les lecteurs de cette revue française.

52 André Parreaux, La société anglaise de 1760 à 1810 (Paris, PUF, 1966), 14. De fait, il a été calculé que, de 1734 à 1832 , les trois quarts des quelque 5,000 représentants à la House of Commons "were mainly concerned with land rather than with other forms of wealth". Gerrith P. Judd, Members of Parliament, 1734-1832 (New Haven, Yale University Press, 1955), 71. On trouvera dans cet ouvrage une étude détaillée sur le statut social, la profession et le milieu culturel des membres du Parlement.

53 Sir Lewis Namier, England in the Age of American Revolution ( $2^{\circ}$ édition, Londres, 1961), 10. 
nant quelques centaines de great Landlords qui, au moyen d'un patronage érigé en système, contrôlaient plus de la moitié des sièges de la House of Commons. ${ }^{54}$ On y comptait alors 558 représentants dont 489 pour l'Angleterre, 45 pour l'Ecosse et 24 pour le pays de Galles. La représentation de l'Angleterre se répartissait de la façon suivante: 40 comtés et 198 bourgs à deux représentants chacun; 5 bourgs à un représentant chacun; la City de Londres avait droit à quatre représentants seulement et les universités de Cambridge et d'Oxford - ces centres aristocratiques de formation académique - étaient représentées à la Chambre par chacune deux membres élus par les seuls "doctors and masters of arts". Dans ces 245 circonscriptions électorales, on dénombrait moins de 300,000 électeurs, soit à peine 5\% de la population; les bourgs qui, à eux seuls, fournissaient plus de $80 \%$ de la représentation, comptaient moins de 125,000 électeurs. Avec un électorat aussi restreint, l'administration gouvernementale, forte de l'appui de la Cour, avait beau jeu de s'adonner sur une haute échelle à la pratique du patronage, notamment dans ce qu'on dénommait les "bourgs pourris". L'électeur considérait son vote "as the placeman his place or the contractor his contract: it was a piece of property which must be made to return a dividend, either in the form of favours from his patron or a cash equivalent".55 Dans ces conditions, on peut imaginer ce qu'il pouvait en coûter pour se faire élire et les faveurs que l'on attendait en retour des dépenses encourues. Ainsi se tissait la trame des liens étroits qui unissaient entre eux les membres de l'oligarchie aristocratique. "The magnates needed the Court as much as the Court needed the magnates: without the resources of the borough patrons the Court could not bring its influence to bear on the House of Commons, but without the rewards of office for themselves and their clients the patrons could not maintain their own influence." 56 Aussi n'y a-t-il pas lieu de s'étonner si, comme le fait justement remarquer l'historien J. H. Plumb, "patronage has been, and is, an essential feature of the British structure of power ... It was patronage that cemented the political system, held it together, and made it an almost impregnable citadel, impervious to defeat, indifferent to social change." 57 La corruption électorale était une pratique si répandue qu'elle ne pouvait échapper à l'attention d'observateurs étrangers. Denis Diderot ne s'y trompait pas en

54 A ce sujet, voir Sir Lewis Namier, The Structure of Politics at the accession of George III ( $2^{\mathrm{e}}$ édition, Londres, 1957).

55 Derek Jarrett, Britain, 1688-1815 (Londres, 1965), 41.

56 Ibid., 42.

57 J. H. Plumb, op. cit., 187-188. 
relatant les impressions que lui rapporta d'Angleterre son ami le baron d'Holbach: "Le monarque paraît avoir les mains libres pour le bien et liées pour le mal; mais il est autant et plus maître de tout qu'aucun autre souverain. Ailleurs la cour commande et se fait obéir. Là, elle corrompt et fait ce qui lui plaît, et la corruption des sujets est peut-être pire à la longue que la tyrannie." 58

Cette dénonciation de l'influence corruptrice de la Cour rencontrait celle de ses contemporains d'Outre-Manche qui, de Londres, animaient le courant de la première vague réformiste qui déferla sous le règne de George III au cri de ralliement "Wilkes and Liberty".59 Au printemps 1767, le publiciste et libraire John Almon lança une revue mensuelle, le Political Register, qui servit la cause de tous ceux qui réclamaient l'application de diverses réformes parlementaires pour remédier, soit à la corruption électorale, soit à l'injuste et inégale représentation de la population à la House of Commons. A la veille des élections de 1768, Almon publia un "numéro extraordinaire" dans lequel il dénonça l'influence corruptrice de l'oligarchie aristocratique en remettant en question le fonctionnement de la constitution britannique depuis la Révolution glorieuse de 1688: ${ }^{60}$

The power of the grandees is ... become more formidable than ever. Their numbers, their privileges, their court emoluments, their influence in elections, their weight in the law, the army, the navy, the church, and the public offices, are all, to an unexampled degree increased ...

58 Lettre de Diderot à sa chère amie Sophie Volland, le 6 octobre 1765. G. Roth et J. Varloot, éd., Correspondance de Diderot (16 vol., les Editions de Minuit, Paris, 1955-1970), V : 129. Ce jugement contraste fort avec celui de Voltaire qui, trente ans plus tôt, faisait cet éloge de la constitution britannique: "La nation anglaise est la seule de la terre qui soit parvenue à régler le pouvoir des rois en leur résistant, et qui, d'efforts en efforts, ait enfin établi ce gouvernement sage, où le prince, tout-puissant pour faire le bien, a les mains liées pour faire le mal, où les seigneurs sont grands sans insolence et sans vassaux, et où le peuple partage le pouvoir sans confusion." Lettres philosophiques ou Lettres anglaises (1734): huitième lettre.

59 Parmi les principaux ouvrages traitant de ce sujet, voir Ian $\mathbf{R}$. Christie, Wilkes, Wyvill and Reform. The Parliamentary Reform Movement in British Politics, 1760-1785 (Londres, 1962) et George Rudé, Wilkes and Liberty. A Social Study of 1763 to 1774 (Oxford, 1962). Pour une plus large synthèse parue récemment: John Cannon, Parliamentary Reform, 1640-1832 (Cambridge, 1973).

60 Political Register Extraordinary, II (1768): 218-225. On y trouve l'article cité de John Almon sous le titre de "Regulus: or a View of the present State of public Affairs with certain Proposals, addressed to the independent Electors of Great Britain". 
The state reformers at the Revolution [1688] were so intent on binding down our kings to their good behaviour, that they left the grandees in possession of powers inconsistent with the first principles of liberty. For what can be imagined more contradictory to the natural rights of mankind, than that... two or three hundred persons should have it, at any time, in their power to stop the whole business of the nation? / ...

Dans ce violent réquisitoire qui, au dire d'un historien, annonçait "the whole of early nineteenth-century radicalism", 61 John Almon s'en prenait à l'écrasante prépondérance de l'aristocratie foncière qui privait la bourgeoisie urbaine de sa juste part de participation à la législation gouvernementale: ${ }^{62}$

The monied interest is not represented at all. One hundred millions and upwards of property wholly excluded from a share in the legislature! excepting where the proprietors have other qualifications. The case is much the same with the commercial interest. A merchant or manufacturer, who exports to the value of half a million [pounds sterling] every year, is not represented as a merchant or manufacturer: he has not the privilege of a beggar in a Cornish borough. Accordingly the great manufacturing towns of Manchester, Birmingham, Sheffield, Sc., have no representation in parliament. And in most towns the corporation, which bears no proportion to the inhabitants, either in number, or property, are the only voters. / ...

Tel fut, dans les faits, l'aboutissement de la "révolution bourgeoise" anglaise du XVIIe siècle qui, dans l'esprit de l'historien Soboul, rendit possible "un compromis social et politique associant au pouvoir bourgeoisie et aristocratie"!

Tout le long du règne de George III, les divers programmes de réformes parlementaires que proposèrent différents groupes et associations connurent le même sort: ils échouèrent aux portes du Palais de Westminster. Parmi les multiples causes d'échec de ces mouvements réformistes, mentionnons la faiblesse d'organisation à l'échelle nationale due au morcellement des groupes et des associations, la division des intérêts et la disparité des objectifs (entre les modérés et les radicaux) qui empêchèrent le regroupement des forces et la coordination des efforts, enfin le manque de support et l'indifférence de larges secteurs de la population. On ne saurait sous-estimer, d'autre part,

61 S. Maccoby, English Radicalism, 1762-1785 (Londres, 1955), 84. Ouvrage très utile pour son abondante documentation; on $\mathrm{y}$ trouvera de larges extraits de l'article de John Almon.

62 Voir supra, note 60. 
l'impact de deux événements majeurs, la Révolution américaine et la Révolution française, qui eurent un double effet contrastant: stimuler l'action des réformistes et renforcer la résistance au changement de l'élite dirigeante.

D'une décennie à l'autre, les dirigeants de l'empire éprouvèrent les mêmes réactions qu'ils assortirent à de nouveaux problèmes. De la Déclaration d'Indépendance (1776) à la Déclaration des Droits de l'Homme (1789), l'élite aristocratique détentrice du pouvoir demeura hantée par la peur du républicanisme démocratique destructeur de l'ordre établi et la House of Commons rejeta à forte majorité tout projet de réforme parlementaire qui risquait de saper les fondements de la constitution britannique dont on faisait l'éloge en ces termes, au lendemain de la prise de la Bastille: ${ }^{63}$

The grandeur, importance, and dignity of the British Constitution, should never be absent from an Englishman's mind; if he ceases to have affection for a so fair, so excellent, so beautiful form of government, he deserves to experience that oppression which the other countries feel. To such degeneracy was justly attributed the downfall of the grand Roman Republic; it declined rapidly from a system of the best regulated liberty, to a scene of confusion, of anarchy, and of oppression.

Devant la poussée des forces révolutionnaires bourgeoises, il fallait à tout prix préserver ce "system of the best regulated liberty" qui assurait le contrôle du pouvoir politique aux éléments les plus conservateurs de la société anglaise: la nobility et la gentry. Sous l'égide de l'administration gouvernementale, John Reeves connut un succès considérable en lançant, en 1792, un vaste mouvement loyaliste à la constitution sous le nom "The Association for preserving Liberty and Property against Republicans and Levellers". A la veille de l'exécution de Louis XVI, le public bourgeois londonien n'hésitait pas à interrompre des représentations théâtrales pour entonner "God save the King and Rule Britannia" et, dans les rues, la foule applaudissait au spectacle de ceux qui brûlaient en effigie le citoyen Thomas Paine, forcé de s'expatrier après que la Cour eut condamné pour sédition ses Rights of Man. ${ }^{64}$

63 Editorial du Public Advertiser, numéro du $1^{\text {er }}$ novembre 1790. Ce journal londonien était l'organe officiel de l'administration gouvernementale. C'était évidemment moins l'histoire de l'empire romain qui préoccupait l'éditorialiste que ce qui se passait en France. 124.

64 John Cannon, Parliamentary Reform, 1640-1832 (Cambridge, 1973), 
L'expérience que le jeune William Pitt tenta au début de son administration est fort significative. En accédant au pouvoir, en décembre 1783, ce jeune homme de moins de vingt-cinq ans se montra d'abord favorable au mouvement de réforme parlementaire qu'avait organisé le révérend Christopher Wyvill en s'appuyant sur la gentry du plus important comté d'Angleterre, le Yorkshire. Il s'agissait d'un programme de réformes modérées qui visait, "by legal and constitutional means", d'une part, à réduire le nombre des "bourgs pourris" par l'élimination des plus petits (donc des plus "notables") et d'autre part, à augmenter "in due proportion" la représentation des comtés ruraux et des centres urbains. ${ }^{65} \mathrm{Au}$ printemps 1785 , Pitt présenta à la House of Commons un projet de réforme recommandant d'augmenter la représentation des country gentlemen ainsi que celle de la bourgeoisie urbaine en accordant cinq sièges de plus à Londres et huit sièges aux quatre principales villes d'Angleterre qui n'avaient pas encore de représentants, soit Birmingham, Manchester, Sheffield et Leeds. ${ }^{66}$ Nonobstant tout le prestige dont jouissait un premier ministre, ce projet de réforme, si modéré fut-il, ne put passer en Chambre où il fut rejeté par 248 voix contre 174. Interprétant ce vote, Wyvill jugea que Pitt avait été "most shamefully deserted by the majority of those counties who had so loudly demanded that reformation". ${ }^{67}$ En fait, l'opposition vint de tous ceux qui applaudirent au discours de Lord North: ${ }^{88}$

For his part, he had always conceived that the spirit of the constitution was to be looked for and found in the common law of the land, and in the practice and usage of parliament. It was enough, in his opinion, for the people to be happy and free. With regard to the idea of the country gentlemen making a considerable part of that House, it was a very just one: he was ready to admit, the bulk and weight of that House ought always to be in the hands of the country gentlemen, who were, undoubtedly, the best and most respectable objects of the confidence of the people. Their disinterestedness, their virtue, their public spirit, he admired: they were fitted by their education and their situation in life more peculiarly for members of Parliament, than almost any other description of men; besides, they had the greatest stake in the

65 Ian R. Christie, Wilkes, Wyvill and Reform (Londres, 1962), 68 sqq. 66 Christopher Wyvill, A State of the Representation of the People of England, on the Principles of Mr. Pitt's Plan, in the Year 1785 (Londres, 1793), 9-11.

67 Cité par John Cannon, op. cit., 95. XXV : 461 .

68 Discours du 18 avril 1785. The Parliamentary History of England, 
country after all, and were the most deeply interested in its welfare: because, let what happen, men of business and manufacturers could go and get their living elsewhere; but a country gentleman could not quit his native country, because he could not carry his estate away with him.

En exposant ainsi les raisons de la prédominance des "Landed Interests" dans la composition de la Chambre, l'ex-premier ministre North entendait rappeler à la nouvelle administration gouvernementale qu'il fallait laisser intacte la structure politique de la société aristocratique anglaise en vertu d'une constitution louée et vénérée - "the work of infinite wisdom ... the most beautiful fabric that, perhaps, had ever existed from the beginning of time". ${ }^{69}$ Il s'opposait à tout changement dans la représentation parlementaire qui risquerait de déséquilibrer le rapport des forces en présence.

De l'échec de son projet de réforme parlementaire, Pitt tira une leçon pour toute la durée de sa première administration jusqu'en 1801. Non seulement ne renouvela-t-il pas cette expérience, mais face aux bouleversements sociaux qui se produisirent en France, il devint réfractaire aux différentes propositions qu'une nouvelle vague réformiste fit affluer dans l'enceinte de la House of Commons au cours de la dernière décennie du siècle. Ce fut le secrétaire d'Etat W. W. Grenville qui donna les premiers signes de résistance de l'administration gouvernementale au "dangereux esprit d'innovation" d'une minorité de sympathisants au mouvement révolutionnaire français. En mars 1790, il déclara en Chambre "that under what circumstances, and at whatever time any proposition of parliamentary reform ... he, for one, would resist it"; d'ailleurs, "the circumstances and times were such, as made not only the question dangerous, but the discussion of it dangerous likewise".70 Pitt prit même à son compte les arguments des plus conservateurs

69 Ibid.: 456. Rappelons qu'au dix-huitième siècle, l'on se représentait la constitution britannique comme une "mixed and balanced constitution" qui, en théorie mais non en pratique, permettait un juste partage et un parfait équilibre des pouvoirs entre les trois corps de la nation (la royauté - la noblesse - le peuple), ce qui faisait dire à Bolingbroke: "It is by this mixture of monarchical, aristocratical, and democratical power, blended together in one system, and by these estates balancing one another, that our free constitution of government hath been established." Dissertations upon Parties (Londres, 1735), 204. On sait que le baron de Montesquieu y trouva le modèle de gouvernement par excellence pour défendre les intérêts de la classe nobiliaire française. Voir L'Esprit des Lois (1748), livre IX: chapitre VI.

70 Discours du 4 mars 1790. The Parliamentary History of England, XXVIII: 470 . 
pour s'opposer aux réformistes: "The security of all the blessings we enjoyed [under the present constitution] would be shaken to the foundation." 71 Son "apostasie" de la cause de la réforme parlementaire lui attira de sévères critiques comme en témoigne cette lettre publique dont il aurait pu difficilement récuser la juste remontrance de son auteur anonyme: ${ }^{72}$

The discussion produced by the French Revolution had given birth to exaggerated ideas of liberty on one hand, and furnished a ground to some men, and a pretext to more, for exaggerated fears of anarchy on the other... It was in your choice to mitigate extremes, to conciliate differences, to extend the impartial beneficience to all parties and sects of citizens. But you chose to take the most effectual means to exaggerate extremes, to inflame differences, to give sanction and countenance of power to one party, to put the Government of the country at the head of a thriumphant faction. You disseminated alarms of designs to subvert the Constitution so widely and so successfully, that you have created in this country a spirit of Toryism more indiscriminate, more abject, and more rancunous than had existed in England since the accession of the House of Hanover.

Et après avoir rappelé l'habile exploitation que jadis Sir Robert Walpole avait faite de la terreur populaire du Jacobitisme pour consolider son pouvoir personnel, ce publiciste reprochait au premier ministre Pitt de se servir du Jacobinisme aux mêmes fins : ${ }^{73}$

You could not fail to recollect the happy use which the dread of Jacobitism was of to Sir Robert Walpole, and you easily saw that the dread of Republicanism might be an equally successful engine in your hands. The reformers of abuse are in such cases called enemies to establishment. The enemies of the Government are to be called enemies of the Constitution.

C'est ainsi que les principaux chefs des groupes contestataires de l'ordre établi furent pourchassés et emprisonnés par l'appareil judiciaire de l'Etat et, qu'à la fin du siècle, William Pitt "presided over a country in which opposition had been beaten into submission". ${ }^{74}$

71 Discours du 30 avril 1792. Ibid., XXIX : 1308.

$72 \mathrm{~A}$ Letter to the Right Honourable William Pitt, on his Apostacy from the cause of Parliamentary (Londres, 1793), 38-40.

$73 \mathrm{Ibid}$., 40. Les Jacobites furent partisans du retour de la Maison des Stuart après l'expulsion de James II du trône d'Angleterre; ils fomentèrent deux soulèvements successifs, en 1715 et en 1745 .

74 John Cannon, op. cit., 134. 
Les débuts de la révolution industrielle en Grande-Bretagne coïncidant avec la poussée des forces révolutionnaires en France, l'élite aristocratique anglaise put compter sur l'appui des nouveaux entrepreneurs manufacturiers pour organiser la répression des mouvements de contestation. ${ }^{75}$ Si dans l'Europe continentale, la fin de l'Ancien Régime et la formation de l'empire napoléonien avaient entraîné la chute des aristocraties de vieille garde, par contre, dans la fière Albion, "the English aristocracy amid all its blunders and errors kept its character for endurance and fortitude". ${ }^{76}$ L'un de ses plus illustres représentants, le héros de Waterloo, le duc de Wellington, préféra abandonner son poste de premier ministre, en 1830 , plutôt que de modifier sa vision de l'ordre politico-social qui lui commandait de résister à la pression des nouvelles forces socio-économiques engendrées par la révolution industrielle. Dans le grand débat qui précéda la réforme électorale de 1832, devant ses pairs de la House of Lords, le duc de Wellington prononça un discours qui synthétisa la conception de la constitution britannique que, depuis la Révolution glorieuse de 1688, les dirigeants de l'empire avaient réussi à faire prévaloir pour se maintenir au pouvoir: ${ }^{77}$

It is only by the influence of property over the elections of members of the House of Commons, and by the influence of the Crown and of this House [of Lords], and of the property of the country upon its proceedings that the great powers of such a body as the House of Commons can be exercised with discretion and safety... This [Reform] Bill must increase beyond measure the democratic power of the State... If this democratic Assembly should once be established in England, does any man believe that we should continue to enjoy these vast advantages? A democracy has never been established in any part of the world that has not immediately declared war against property ... and against all the principles of conservation, which are secured by and are, in fact, the principal objects of the British Constitution, as it now exists.

75 "The French Revolution consolidated Old Corruption by uniting landowners and manufacturers in a common panic; and the popular societies were too weak and too inexperienced to effect either revolution or reform of their own." E. P. Thompson, The Making of the English Working Class (Londres, 1963), 178.

76 Selon l'expression des historiens J. L. et Barbara Hammond rapportée dans A. Goodwin, ed., The European Nobility in the Eighteenth Century (Londres, 1952), 21.

${ }_{77}$ Discours du 4 octobre 1831. Hansard's Parliamentary Debates, Third Series, vol. 7: 1198 sqq. Les extraits cités sont reproduits dans Cecil S. Emden, ed., Selected Speeches on the Constitution (2 vol., "The World's Classics", Oxford, 1939), II : 150-151. 
Ce discours marqua la fin d'une ère antiréformiste. L" "Age des réformes" qui suivit devait rendre possible la mise au rancart d'une constitution coloniale conçue en fonction d'un système de valeurs propre à une société pré-industrielle.

La genèse de la Constitution de 1791 remonte au lendemain du traité de Paris qui sanctionna, en février 1763, la cession définitive du Canada à la Grande-Bretagne. C'est au cours des mois qui suivirent que, du côté métropolitain, l'on supputa diverses solutions aux problèmes de la pacification, de l'organisation et de l'administration de cet immense territoire conquis s'étendant du golfe Saint-Laurent jusqu'aux sources du Mississipi et englobant la vaste région des Grands Lacs. Il en résulta l'ébauche d'une politique impériale qui, par la Proclamation royale d'octobre 1763, visait à reconstituer un empire colonial dans une Amérique du Nord devenue entièrement britannique. ${ }^{78}$

Cette Proclamation royale s'appuyait sur les recommandations du Board of Trade dont les membres (notamment le président) avaient comme principale responsabilité de conseiller le ministère en matières commerciales et coloniales. ${ }^{79}$ Parmi les nombreux documents qui firent l'objet de la considération du Board of Trade, il s'en trouva un qui reçut une attention toute particulière car son auteur, vraisemblablement Henry Ellis, agissait alors comme conseiller personnel du secrétaire d'Etat Lord Egremont. ${ }^{80}$ Cet important document de travail, intitulé

78 Pour le texte de la Proclamation royale, voir Shortt et Doughty, ed., op. cit., I: 163-168. Rappelons sommairement les principaux points de cette politique impériale: $1^{\circ}$ ) la création de vastes réserves indiennes dans le Middle West américain et la région des Grands Lacs aux fins de "préserver la paix intérieure et la sécurité du continent" - d'où la réglementation du commerce des fourrures et l'établissement de garnisons aux différents postes de l'Ouest; $2^{\circ}$ ) la fixation des frontières de la province de Québec et la limitation de l'expansion coloniale nord-américaine; $3^{\circ}$ ) le peuplement des nouvelles colonies (Québec et les deux Florides) et l'exploitation de leurs ressources naturelles; et $4^{\circ}$ ) l'établissement dans ces nouvelles colonies d'un mode de gouvernement civil prévoyant l'exercice des mêmes droits et privilèges dont jouissaient les sujets britanniques des colonies royales américaines.

79 Voir le Rapport du Board of Trade daté du 8 juin 1763 ainsi que l'échange de correspondance avec le secrétaire d'Etat. Shortt et Doughty, ed., op. cit., I: 127 à 162 .

80 Henry Ellis (1721-1802) avait été gouverneur de Georgie, de 1758 à 1760 , et il avait reçu une commission de gouverneur non résident pour la Nouvelle-Ecosse. De 1764 à 1769, il occupa le poste de "secrétaire provincial" au Conseil du gouverneur de Québec. Le procureur général Francis 
"Hints relative to the Division and Government of the conquered and newly acquired Countries in America", contenait des propositions qui, en majeure partie, furent endossées par le ministre Egremont. 81 L'application de deux recommandations allait cependant être reportée à près de trente ans plus tard: la division du Canada en deux provinces et l'établissement d'une Chambre d'Assemblée au profit des "nouveaux sujets" de sa Majesté. Voyons en quels termes ces deux éléments fondamentaux de l'Acte constitutionnel de 1791 furent énoncés au lendemain de la Conquête :82

The Country call'd Canada is of such vast Extent, that, for the greater Convenience of governing its Inhabitants there seems to be a Necessity of dividing it into two Provinces at least, and of establishing in each a distinct Government.

Quebec, of course, should be the Capital of the Lower province, comprehending the Isle of Orleans, the Settlements on the South Eastern Banks of St. Lawrence... and all the Territory on the North West Side of that River, lying to the Eastward of Trois-Rivières.

Montreal might with equal propriety be made the Capital of the Upper province, which may include not only that Tract of Land between Lake Champlain and St. Lawrence but likewise all the Country on the North Side of that River above Trois-Rivières.

The Civil Government of these Provinces would be best administered for some time, by a Governor \& Council only, who should be vested with the same legislative Powers as have been conferred on the General Assemblies in those provinces where the Royal Government has been settled in it's greatest purity; and when circumstances are so much changed as to render it expedient, His Majesty may indulge His new Subjects ... with Representatives in General Assembly which would at once convert what before was a Despotic Government into one of Liberty.

Ainsi dès 1763 , l'idée était lancée qu'un jour les Canadiens pourraient bénéficier des "libertés anglaises" lorsqu'un changement

Masères attribuait à Henry Ellis la rédaction de la Proclamation royale de 1763 et il le considérait comme "the oracle of the ministry for all American matters". Voir lettres adressées à Fowler Walker, les 19 novembre 1767 et 11 août 1768, dans W. S. Wallace, ed., The Masères Letters, 1766-1768 (Toronto, 1919).

81 Ce document est reproduit avec une présentation annotée de Werner W. Crane, dans The Mississipi Valley Historical Review, VIII, no 4 (1922): 367 à 373

82 Ibid.: $370-371$. 
de circonstances en rendrait la concession nécessaire. C'est ce qui se produisit lorsque l'établissement de plusieurs milliers de Loyalistes dans la future province du Haut-Canada créa des conditions favorables à la formation de deux gouvernements provinciaux dotés chacun d'institutions représentatives.

L'expansion de l'empire britannique en Amérique du Nord incita les dirigeants métropolitains à envisager différentes mesures de contrôle impérial qui, comme l'on sait, provoquèrent les treize colonies américaines à la révolte. C'est sous l'administration de George Grenville que débuta la série des décrets parlementaires qui, culminant avec les "Coercive Acts" de 1774, mirent finalement le feu aux poudres. Ce fut sous ce ministère que se fit connaître un jeune homme du nom de William Knox qui allait être appelé à participer étroitement à l'élaboration de la politique impériale durant toute la période révolutionnaire, à titre de sous-secrétaire d'Etat pour les colonies américaines. ${ }^{83}$ C'est en commençant sa carrière politique comme membre du Conseil de Georgie où il devint l'un des "favoris" du gouverneur Henry Ellis que William Knox s'acquit la réputation d'expert colonial. ${ }^{84}$

De retour à Londres après cinq années de service civil en Amérique, William Knox prépara, à l'intention des autorités métropolitaines, un projet de restructuration des gouvernements coloniaux. ${ }^{85} \mathrm{Il}$ avait pu constater sur place les tensions croissantes qui existaient entre les administrateurs coloniaux nommés par la Couronne et les représentants choisis par le peuple dans les assemblées législatives provinciales. Il posa comme diagnostic

83 William Knox (1732-1810) prétendit lui-même avoir été "a principal actor in the executive Government" sous l'administration de Lord North (de 1770 à 1782). Voir ses Extra Official State Papers (2 vol., Londres, 1789), II : 3-4. Il appuya le plan féodal du gouverneur Sir Guy Carleton et il prit la défense de l'Acte de Québec dans deux écrits publics parus à Londres en 1774: The Justice and Policy of the late Act of Parliament for making more Effectual Provision for the Government of the Province of Quebec - Thoughts on the Act... for the Government of the Province of Quebec. Sur l'importance du rôle des sous-secrétaires d'Etat William Knox et John Pownall durant la Révolution américaine, voir Margaret M. Spector, The American Department of the British Government, 1768-1782 (Columbia University Press, 1940) et Franklin B. Wickwire, British Subministers and Colonial America, 1763-1783 (Princeton University Press, 1966).

84 Margaret M. Spector, op. cit., 102.

85 "Hints respecting the Civil Establishments in the American Colonies" (1763). On trouvera la reproduction intégrale de ce document accompagné d'une présentation annotée par Thomas C. Barrow, dans "A Project for Imperial Reform", The William and Mary Quarterly, Third Series, XXIV, n० 1 (1967) : 108-125. 
"an excess of Power in the hands of the People" attribuable au fait que les colons américains considéraient avoir droit "to a greater measure of Liberty than is enjoyed by the People of England, because of their quitting their Native Country, to make Settlements for the advantage of Great Britain", d'où, en conséquence, "the perpetual struggle in every Colony between Privilege and Prerogative" - les privilèges des sujets et les prérogatives du roi. Ce fut une erreur capitale, selon lui, d'avoir accordé de plus grands privilèges aux deux colonies à chartes (Connecticut et Rhode Island) et aux trois colonies de propriétaires (Maryland et Pennsylvanie-Delaware) qu'aux huit autres colonies royales: ${ }^{88}$

It was surely not the likeliest method of teaching the Americans (who are not by descent lovers of Monarchy) a reverence for the Kingly authority to show them that where the Crown had least power the People were most free, and that a Fellow subject would allow them greater privileges under his government that their Sovereign would suffer them to enjoy, where the Modelling the Constitution was in himself.

Pour remédier à ce déséquilibre constitutionnel, Knox recommandait l'intervention du Parlement britannique qui, dans un premier temps, révoquerait les chartes accordées aux colonies du Connecticut et du Rhode Island et rachèterait les droits de propriété des colonies du Maryland et de Pennsylvanie-Delaware, puis

when this is done, let one Mode of Government be prescribed for all the Colonies and fully set forth in an Act of Parliament, and the observance enjoyned by proper Sanctions. The interposition of Parliament is absolutely necessary for all these purposes, not only because the Crown can neither revoke its Charters, nor abrogate Laws, which have received the Royal Assent, but because no other Authority than that of the British Parliament will be regarded by the Colonies, or be able to awe them into acquiescence.

Ces "grandes réformes" réalisées, il y aura lieu de s'attaquer à d'autres maux, principalement à la trop grande dépendance des "Officiers de la Couronne" vis-à-vis des législatures locales: ${ }^{87}$

The King's Officers are the natural, and constitutional supporters of the Prerogative, and in the Colonies their assistance is more necessary than even here [in England]... But how can it be expected that Officers who derive little else than

86 Ibid.: 117.

87 Ibid.: 118. 
their Commissions from the Crown, and are dependent on the good will of the Assemblies for their subsistance, should stand forward and combat with the Assemblies in support of the Prerogative?

La Révolution américaine allait démontrer le bien-fondé du diagnostic posé par William Knox lorsque, vingt ans plus tard, les dirigeants de l'empire décidèrent d'appliquer les remèdes qu'il avait prescrits. Dans un British North America limité au $45^{\circ}$ parallèle, l'administration de William Pitt crut pouvoir prévenir les maux résultant d'un "excess of Power in the hands of the People" en formant des gouvernements coloniaux bien assujettis aux prérogatives royales. Elle devait aussi mettre en application les réformes constitutionnelles qu'avait proposées, à la veille de la crise du Stamp Act, Sir Francis Bernard, l'exgouverneur du Massachusetts: ${ }^{88}$

There is no Government in America at present, whose powers are properly balanced; there not being in any of them a real and distinct third Legislative power mediating between the King and the People, which is the peculiar excellence of the British Constitution.

The want of such a third Legislative power, adds weight to the popular, and lightens the scale: so as to destroy the balance between the royal and popular powers.

Although America is not now (and probably will not be for many years to come) ripe enough for an hereditary Nobility; yet it is now capable of a Nobility for life.

A Nobility appointed by the King for life, and made independent, would probably give strength and stability to the American governments, as effectually as an hereditary Nobility does to that of Great Britain.

Que pouvait-on imaginer de mieux pour faire croître dans les forêts d'Amérique "where all Men appear nearly upon a Level" ${ }^{89}$ les lauriers de la constitution britannique?

88 "Principles of Law \& Polity, Applied to the Government of the British Colonies in America" (1764). Ce mémoire rédigé à l'intention des autorités métropolitaines fut rendu public, avec un choix de lettres, dans un opuscule intitulé Select Letters on the Trade and Government of America (Londres, 1774). Sir Francis Bernard (1712-1779) avait exercé sa profession d'avocat durant une vingtaine d'années en Angleterre avant d'être nommé gouverneur du New Jersey, puis du Massachusetts, de 1760 à 1769 .

89 Selon l'expression de Sir Guy Carleton qui déplorait le peu d'influence et de prestige dont jouissait le gouverneur alors que son devoir lui commandait "to retain all in proper Subordination". Voir lettre à Lord Shelburne, le 20 janvier 1768. Shortt et Doughty, ed., op. cit., I: 296. 
L'indépendance de la jeune République américaine fut reconnue par la signature d'articles préliminaires de paix, le 30 novembre 1782. Une généreuse portion de l'héritage colonial de la Nouvelle-France, du côté de l'Ouest, avait été cédée aux Américains par Lord Shelburne, ${ }^{90}$ qui désirait prévenir "all future Risque of Enmity" et établir "the foundation of a new Connection" entre l'ancienne métropole et les nouveaux Etats indépendants. ${ }^{91}$ Tout au cours des négociations de paix, la question de la délimitation des frontières du British North America avait été rattachée au problème que posait le rapatriement des "King's Loyal Subjects" au sein de l'empire. Ces dignes fils de la mère patrie qui avaient prouvé leur attachement à la Couronne en combattant leurs frères rebelles méritaient qu'on se préoccupe de leurs futurs établissements en Amérique du Nord; cette nécessité fut l'une des principales raisons qui incitèrent les négociateurs britanniques à résister à l'avidité territoriale des Américains. ${ }^{92}$

Les généreuses conditions de paix consenties par le premier ministre Shelburne avaient suscité la réprobation de la majorité des membres du Parlement qui n'étaient pas préparés à accepter les principes du libéralisme économique prônés par ce nouveau disciple d'Adam Smith déclarant devant ses pairs de la House of Lords : ${ }^{93}$

90 De juillet 1782 jusqu'à sa démission en février 1783, Lord Shelburne avait pris la tête de l'administration de feu le marquis de Rockingham. A titre de secrétaire d'Etat, poste qu'il occupait depuis mars 1782, il dirigea personnellement les négociations de paix.

91 Lettre de Lord Shelburne à Richard Oswald, son principal agent négociateur, le 22 juillet 1782. Citée par Vincent T. Harlow, The Founding of the Second British Empire, 1763-1793 (2 vol., 1954-1964), I: 232. Lord Shelburne désirait établir de nouvelles relations commerciales avec les EtatsUnis afin de faire bénéficier la Grande-Bretagne d'un vaste marché pour l'écoulement de ses produits manufacturés et, dans cette perspective, il voyait surtout l'utilité du Canada "as a trade corridor" donnant accès, par sa voie fluviale, au Middle West. C'est ce qui explique qu'il ait pu aussi libéralement laisser amputer au profit des Américains la vaste région des Grands Lacs - cette grande source d'approvisionnement des marchands de fourrures du Canada. Le monopole de traite de la bourgeoisie coloniale importait beaucoup moins à ses yeux que les avantages économiques d'un "Anglo-American partnership".

${ }_{92} \mathrm{Au}$ sujet de ces négociations de paix, voir l'excellent ouvrage de Richard B. Morris, The Peacemakers: the Great Powers and American Independence (New York, 1965).

93 Discours du 17 février 1783, à l'occasion des débats sur les articles préliminaires de paix. The Parliamentary History of England, XXIII : 409-410. 
Situated as we are between the old world and the new, and between the southern and northern Europe, all that we ought to covet upon earth is free trade, and fair equality. With more industry, with more enterprize, with more capital than any trading nation upon earth, it ought to be our constant cry, let every market be open, let us meet our rivals fairly, and ask no more.

Mais il fallait plus qu'un simple discours "putting a brave rhetorical gloss on a grave imperial disaster" 94 pour convaincre les représentants de la nation de délaisser le traditionnel "Old Colonial System" au profit d'un empire fondé sur le "Free Trade". Lord Shelburne l'apprit à ses dépens en se voyant forcé de démissionner et d'abandonner l'espoir de conclure avec les Etats-Unis une entente commerciale fondée "on the most enlarged principles of reciprocal benefit for both countries". ${ }^{95}$ La présentation en Chambre de ce projet, connu sous le nom de "American Intercourse Bill", avait provoqué les plus vives réactions de la part des défenseurs du protectionnisme impérial. "This Bill, déclara William Eden, would introduce a total revolution in our commercial system" ${ }^{96}$ et Lord Sheffield, qui passa à l'histoire comme "the great protector of British Trade and Commerce", lança un avertissement solennel aux dirigeants de l'empire en proclamant que le moment était venu de décider "whether we were to be ruined by the Independence of America or not": 97

The principle of the Navigation Act should be kept entire; the country was as tenacious of the principle of that Act as it possibly be of the principle of Magna Charta. The ministers

94 Ronald Hyam, "British Imperial Expansion in the late Eighteenth Century", The Historical Journal, X, no 1 (1967) : 114. Lord Shelburne lui-même avouait au roi, en septembre 1782, que les "neuf-dixièmes" de la nation demeuraient attachés aux principes du système mercantiliste et qu'il faudrait convertir les esprits "before any such fundamental change could be thought in our Commercial System". Sir John Fortescue, ed., The Correspondence of King George the Third (6 vol., Londres, 1927-1928), VI: 136.

95 Cette entente commerciale prévoyait le libre accès aux ports des Antilles britanniques des navires américains transportant des produits cultivés et manufacturés aux Etats-Unis. Pour le texte de cet "American Intercourse Bill", voir V. T. Harlow et F. Madden, ed., British Colonial Developments, 1773-1834 (Oxford, 1953), 249-250.

96 Discours à la House of Commons, le 7 mars 1783 . The Parliamentary History of England, XXIII: 602. William Eden (1774-1814), créé baron Aukland en 1789, fut successivement président du Board of Trade, soussecrétaire d'Etat, conseiller privé du roi, ambassadeur et diplomate.

97 Discours à la House of Commons, le 15 avril 1783. Ibid.: 763-764. Lord Sheffield alerta l'opinion publique en publiant ses célèbres Observations on the Commerce of the American States (1783) où il reprit, en la développant, l'argumentation qu'il avait soutenue en Chambre. 
should understand that the carrying trade must not be given up; they must reserve to our remaining dominions the exclusive trade to West Indies Islands, otherwise the only use of them would be lost... The Navigation Act gave us the trade of the world...

S'il fallait permettre aux navires américains le libre accès aux ports des Antilles britanniques ("British West Indies"), il s'ensuivrait non seulement "the great decrease of our revenue, but the destruction to our navy, arising from the destruction of that great nursery of seamen".98 $\mathrm{Ne}$ serait-ce pas courir le risque de mettre en péril l'empire maritime qui faisait la gloire, la grandeur et la supériorité de la nation britannique ? Que deviendrait Albion sans Neptune? - "They rule the balanc'd world, who rule the main", avait chanté le poète Richard Glover.

C'est ainsi qu'au lendemain de l'Indépendance des EtatsUnis, l'on opta pour le maintien du "Old Colonial System" dans sa forme la plus rigide, ce qui eut pour conséquence de raffermir plutôt que de relâcher l" Imperial Rule" sur le British North America. ${ }^{99}$ Et avec la perspective d'un regain de colonisation britannique, grâce à l'arrivée massive des Loyalistes en NouvelleEcosse et au Québec, l'on se prit à entretenir le rêve de reconstituer "a new self-contained Western Empire in which British North America ... should take the place of the revolted colonies, and supply the raw materials and foodstuffs required by the British West Indies". 100 Ce rêve devait être de courte durée, à peine le temps de créer quatre provinces sœurs.

Quelques mois après son accession au pouvoir, l'administration de William Pitt le Jeune remplaça le défunt Board of Trade par un comité du Conseil privé désigné sous le nom de "Committee for Trade" 101 qui fut chargé de s'enquérir sur les diffi$604-605$

98 D'après William Eden lors du discours cité supra, note 96. Ibid.:

${ }_{99}$ A ce sujet, voir W. R. Brock, The Effect of the Loss of the American Colonies upon British Policy (The Historical Association, Londres, 1966).

ioo Eric Robson, The American Revolution in its Political and Military Aspects (Londres, 1955; réédité "The Norton Library", New York, 1966), 230. Il fallut moins d'une décennie pour se rendre compte que les produits américains étaient non seulement indispensables aux Antilles britanniques mais même nécessaires à la survie du Canada. Le temps devait donner raison à Lord Shelburne et à ses promesses d'avenir d'un "Anglo-American partnership".

101 Ce comité avait été formé par Ordre en Conseil du roi, le 5 mars 1784, "for the consideration of all matters relating to Trade and Foreign Plantations". 
cultés d'approvisionnement des Antilles britanniques par suite de la nouvelle politique impériale. ${ }^{102}$ Cette enquête offrit l'occasion d'entendre divers témoignages sur les perspectives d'avenir de la colonisation britannique en Amérique du Nord. Les membres du Comité furent séduits par les descriptions enthousiastes qu'on présenta des multiples ressources exploitables qui feraient du British North America "a future colonial granary, a vast reserve of naval stores and timber, and a potential market for British manufactures and West Indian rum". ${ }^{103}$ Ils remirent un rapport des plus optimistes comme en font preuve ces quelques extraits : ${ }^{104}$

By Information which the Committee received... it was clearly proved... that the Province of Canada is able to export great Quantities of Wheat and Flour for the Consumption of the British India Islands... It appears also to the Committee that great Quantities of Lumber can be furnished from Canada... Nova Scotia will soon be able to supply great Quantities of Lumber, and if Grants of Lands are properly made and secured to the Inhabitants they will in about three years be able to furnish at moderate prices most of the Articles which the West India Islands can want from North America ... The Loyalists who are lately gone there ... are industrious, extremely anxious to cultivate the Land alloted to them, and to enter into any Plan by which they can exist under the British Government.

Avec un tableau aussi reluisant et avant que le temps n'en montrât les mirages, les autorités métropolitaines furent disposées à recevoir favorablement les demandes de ces valeureux pionniers loyalistes désireux de faire fructifier le sol canadien et de transformer le pays en une terre d'abondance.

Ce fut précisément en ce printemps 1784 que les Loyalistes reçurent l'assurance d'obtenir ce qu'ils souhaitaient depuis leur arrivée en Nouvelle-Ecosse: "A seperate Government [which]

102 Par Ordre en Conseil, daté du 2 juillet 1783, le ministère FoxNorth avait décidé de réserver aux seuls sujets britanniques le transport de certaines catégories de produits américains (tels le bois, les céréales, les légumes et les bestiaux) indispensables à la survie des Antilles, dans l'attente, espérait-on, que le British North America puisse les approvisionner complètement. Voir V. T. Harlow, op. cit., I: 476 sqq.

103 Gerald S. Graham, Sea Power and the British North America, 1783-1820 (Harvard University Press, 1941), 40-41.

104 Public Record Office (PRO), B.T., 6/181: f. 34-40. Ce rapport du "Committee for Trade" était daté du 31 mai 1784. Voir les commentaires de G. S. Graham (op. cit., 30-31) . 
shall be the most Gentlemanlike one on earth." ${ }^{105}$ Cette séparation répondait à des objectifs politiques fort bien exprimés par Sir Guy Carleton lorsqu'il fut appelé à témoigner devant le comité du Conseil privé en mars 1784: "The only firm hold that Great Britain has upon the remains of the American Dominions is certainly by means of the Loyalists." 106 N'était-il pas indiqué de conserver la ferveur royaliste de ces zélés défenseurs de la constitution britannique en les prémunissant contre l'influence pernicieuse du républicanisme qui s'était infiltrée dans les milieux d'Halifax? C'est ce que William Knox avait recommandé à Lord North, en 1783, en lui soumettant un projet de gouvernement provincial séparé pour les Loyalistes. Il y proposait: ${ }^{107}$

to erect the country from the river St. Croix to the Gulph of St. Lawrence, and from the Line across the Isthmus to the Line of Canada, into a new province, placing the seat of Government on the river St. John... They will gladly receive a Constitution calculated to cherish monarchical principles, and to repress republican ideas, and of a tendency to bind them to Great Britain; and it will be the fault of Administration if such a Constitution be not established, as will render their union with this country happy and permanent.

Ainsi fut officiellement fondé, en juin 1784, un "removed Loyalist haven in the North". ${ }^{108}$

La fondation du Nouveau-Brunswick créa un précédent dont allaient se prévaloir aussi les Loyalistes établis dans la partie supérieure du fleuve Saint-Laurent pour réclamer le privilège d'une législature provinciale distincte. Ces milliers de nouveaux colons venus trouver refuge au Canada, pour la plupart anciens fermiers originaires des colonies de New York et de Pennsylvanie, entreprirent le développement de la future province du Haut-Canada après que le gouverneur Frederic Haldimand eut décidé, à l'automne 1783 , de les établir à l'ouest de la zone seigneuriale, depuis le Long-Sault jusqu'à la baie de Quinte. ${ }^{109}$

105 Lettre d'Edward Winslow à Ward Chipman, datée de "River St. John's", le 7 juillet 1783. W. O. Raymond, ed., Winslow Papers, 17761826 (New Brunswick Historical Society, St. John, 1901), 100. Winslow (1746-1815) fut l'un des plus ardents protagonistes de cette séparation. 106 "Minutes" du "Committee for Trade", 16 mars 1784. Cité par W. S.

MacNutt, New Brunswick - A History, 1784-1867 (Toronto, 1963), 44. 107 "New Establishment for the American Loyalists" in William Knox,

Extra-Official State Papers, II: Appendice XIV, 53.

108 Selon l'appellation de W. S. MacNutt, op. cit., 12.

109 Les rapports favorables des arpenteurs sur la qualité des terres de cette région et les bonnes dispositions des Indiens à accepter la venue des Blancs déterminèrent le choix du gouverneur Haldimand. Gerald $\mathbf{M}$. Craig, Upper Canada: The Formative Years, 1784-1841 (Toronto, 1963), 4-5. 
Haldimand fit preuve de clairvoyance en plaidant la cause de cette colonisation agricole auprès des autorités métropolitaines: ${ }^{110}$

I am happy to find that there are in the Gift of the Crown, Lands of so good a Soil and in a favorable Climate, sufficient not only to settle the Provincial Corps when disbanded, but all such Royalists as may come from the Southward with a view to find an Asylum from the Tyranny and Oppression of their Countrymen. I foresee great advantages from this Settlement... The Royalists settled together in numbers will form a respectable Body attached to the Interests of Great Britain ... Their industry will in a very few years raise in that Fertile Tract of Country great Quantities of Wheat and other Grains and become a Granary for the Lower Parts of Canada where the Crops are precarious and liable to be engrossed by a few designing and interested Traders...

Cette vision d'avenir d'une province appelée à servir de grenier du Bas-Canada avait le mérite d'être beaucoup plus réaliste que celle de faire du British North America le grand pourvoyeur des Antilles britanniques.

Moins d'un an après l'établissement des Loyalistes dans les nouveaux cantons du Haut-Canada, leurs principaux porte-parole adressèrent une pétition au roi en vue de l'obtention d'une législature distincte, "under the Government of a Lieutenant Governor and Council,... appointed by Your Majesty, with the necessary Power of internal Regulation, but subordinate to the Governor and Council of Quebec".111 Ils justifièrent leurs demandes en faisant valoir la nécessité d'un "Liberal System of Tenure, Law, and Government" pour favoriser le développement et la sécurité de la nouvelle colonie et pour attirer au Canada tous les Américains qui désireraient redevenir sujets britanniques "from their Attachment to Your Majesty, their ancient Predilection in favour of the British Government, their Dislike of the Republican Government they now live under, as well as from their Family, and Personal Attachments". Des fils de la mère patrie qui avaient sacrifié "their Estates and Properties in sup-

110 Lettre d'Haldimand à Lord North, 6 novembre 1783. Reproduite dans E. A. Cruikshank, ed., The Settlement of the United Empire Loyalists on the Upper St. Lawrence and Bay of Quinte in 1784 (The Ontario Historical Society, Toronto, 1934), 23-24.

111 "Petition of Sir John Johnson, baronet, and others in Behalf of the Loyalists settled in Canada", datée de Londres, le 11 avril 1785 . Shortt et Doughty, ed., $o p$. cit., II: 772-774. Cette pétition était signée par les principaux officiers qui avaient commandé des régiments de Loyalistes durant la guerre d'Indépendance américaine. 
port of Your Majesty's Laws and Government" méritaient de jouir des bienfaits de la constitution britannique. ${ }^{112}$

Les demandes des Loyalistes correspondaient si bien aux vues des autorités britanniques que dans les mois qui suivirent leur pétition au roi, l'administration de William Pitt envisagea sérieusement de changer la constitution établie par l'Acte de Québec et de diviser la province en vue de la création de deux gouvernements séparés. Au début de l'année 1786, en prévision du retour de Sir Guy Carleton à titre de gouverneur en chef du British North America, le Conseil privé du roi prépara à son intention des "Instructions particulières" lui enjoignant, aussitôt après son arrivée à Québec, de s'enquérir auprès de la population "to obtain the most full and authentick information of the real sentiments of the Inhabitants" sur les réformes constitutionnelles réclamées par les marchands britanniques et par le groupe réformiste canadien. ${ }^{113}$ Le futur Lord Dorchester devait aussi éclairer les dirigeants métropolitains sur l'opportunité de créer une nouvelle province au Canada: ${ }^{114}$
And whereas from the great extent of Our province of Quebec, as well as the increased Number of Inhabitants, and in par- ticular of those of our Loyal Subjects... who ... retained their allegiance to Us, it may be expedient to divide the same, and erect for the present a distinct and separate province to the Westward: It is Our Will and Pleasure, that You do obtain the most particular information, and transmit Your Opinion, where and in what Manner the proposed division should be made, and also whether the Constitution of such new erected province, ought to be similar to what is at present, or may hereafter be established in Our province of Quebec. or whether the same should be similar to those established in Our other Provinces and Colonies in America...

A toutes ces questions, le gouverneur Dorchester et le juge en chef William Smith, son conseiller, n'apportèrent aucune réponse satisfaisante. A propos de ces deux administrateurs, l'historien Burt porte un jugement sévère mais juste: "Dorchester fumbled with the constitutional problem. It was to him a Gordian knot which he had neither the ability to undo nor the courage to cut, and Smith was no great help to him, for he too was baffled by the complicated situation in the colony." 115

112 Ibid.: $773-777$.

113 "Draught of Particular Instructions to Carleton" (1786). Shortt et Doughty, ed., op. cit., II : 813-815.

114 Ibid.: 815.

115 The Old Province of Quebec, 482. 
Après avoir joué un rôle de tout premier plan dans l'élaboration de l'Acte de Québec, Sir Guy Carleton parut, à son retour au Canada à l'automne de 1786, complètement dépassé par les événements. Elevé à la pairie et âgé de plus de soixante ans, il avait perdu sa ferveur ambitieuse d'antan. Depuis sa démission de son poste de gouverneur de Québec en 1777, il avait connu d'amères déceptions. Son expérience de commandant en chef ne lui avait apporté aucune des satisfactions qu'il espérait de cette nomination du roi. ${ }^{116}$ Loin de pouvoir jouer un grand rôle de pacificateur pour réconcilier les colonies américaines à la mère patrie comme il s'y attendait, il dut se contenter de faire évacuer des dizaines de milliers de Loyalistes. ${ }^{117}$ Durant son séjour à New York, en 1782-83, il avait fait la connaissance de William Smith qui lui fit rêver de devenir un jour le "vice-roi" du British North America. ${ }^{118}$ Carleton abandonna ce rêve après avoir obtenu son titre de noblesse auquel il tenait par-dessus tout: ${ }^{119}$

We had a long Conversation on the British Constitution which he admires as much as I do. He [Carleton] laughed heartily at my Idea that the King \& Queen were the only slaves in the Nation. Assents that an English Peer had a more eligible Standing than any Crown'd Head. Ease, Dignity \& Security. He thought my Observation a very good one that the Aristocracy gave a sleeping Dose to Ambition. There it terminated as there was no going higher. When arrived to the Peerage all Busling ended for the Residue of a Man's Days, and the new elevated Peer became a quiet Citizen.

La plus grande ambition de Carleton se trouva donc comblée ce jour du 19 juillet 1786 où il put baiser la main du roi qui l'éleva au rang des pairs du royaume. Dorénavant Lord Dorchester pouvait vivre avec "Ease, Dignity \& Security".

Deux ans après le retour de Dorchester au Canada, le secrétaire d'Etat rappela au gouverneur la teneur des "Instructions

${ }^{116}$ Le roi George III désigna personnellement Sir Guy Carleton "as the best officer" pour remplacer Sir Henry Clinton à titre de commandant en chef des troupes britanniques en Amérique du Nord. Lettre du roi au secrétaire d'Etat Lord Germain, le 15 décembre 1781. Sir John Fortescue, ed., The Correspondence of King George the Third, V: 333.

${ }_{117}$ A ce sujet, voir l'intéressante étude de Paul H. Smith, "Sir Guy Carleton, Peace Negociations, and the Evacuation of New York", Canadian Historical Review, $\mathrm{L}, \mathrm{n}^{\circ} 3$ (1969): 245-264.

${ }^{118}$ L. F. S. Upton, The Loyal Whig: William Smith of New York \& Quebec (Toronto, 1969), 142.

119 L. F. S. Upton, The Diary and Selected Papers of Chief Justice William Smith, 1784-1793 (The Champlain Society, 2 vol., Toronto, 19631965), II: 23-24. Conversation que Smith nota dans son Journal, en date du 22 novembre 1785. 
particulières" reçues avant son départ de Londres. Lord Sydney prit soin de lui reformuler les questions déjà posées en le pressant de fournir tous les renseignements jugés indispensables afin de mettre le cabinet ministériel en mesure de proposer, si possible dès la prochaine session, "such arrangements as may be found to be expedient for removing every just and reasonable cause of complaint that may exist among His Majesty's Subjects, of any description whatsoever, who are Inhabitants of [the] Province [of Quebec]". ${ }^{120}$ Et manifestement préoccupé par le cas des Loyalistes, le ministre précisa: ${ }^{121}$

as these People are said to be of the number desirous of the Establishment of the British Laws, It has been in Contemplation to propose to Parliament a division of the Province, to commence from the Boundary Line of the Seigneurie granted to Monsieur De Longueil... But, before they take any step towards the execution of this measure, they [His Majesty's Servants] are desirous of receiving the advantage of Your Lordship's opinion how far it may be practicable or expedient; or, whether any other line or mode of separation would be preferable...

Lord Sydney concluait sa lettre par ce qui allait être particulièrement retenu comme solution en 1791 pour le Haut-Canada: ${ }^{122}$

With a view to the execution of the Plan in question, it will be necessary for you to consider, previously to your Report upon it, what sort of Civil Government ought to be formed for its internal arrangement, \& whether the Number and description of the Inhabitants and other Circumstances are such as do, or do not, make the immediate Establishment of an Assembly within this district, practicable and adviseable. At all events It will be natural, as the greatest Part of these New Settlers are attached to the English Laws, that that System should be introduced as the general Rule, with such Exceptions or Qualifications as particular and local Circumstances may appear to require.

En guise de réponses aux questions précises du secrétaire d'Etat concernant l'avenir du British North America, le gouverneur Dorchester se contenta de modifier quelque peu les vagues considérations du juge en chef Smith: ${ }^{123}$

120 Lettre de Lord Sydney à Dorchester, le 3 septembre 1788. Shortt et Doughty, ed., op. cit., II: 956 .

121 Ibid.: 957.

122 Ibid.: 957.

123 Lettre de Dorchester à Lord Sydney, le 8 novembre 1788. Shortt et Doughty, ed., op. cit., II: 958. Pour le projet de réponse préparé par Smith, voir "Draft for Lord Dorchester" (7 novembre 1788), dans L. F. S. Upton, ed., The Diary and Selected Papers ... II : 246-250. 
A change of the laws and form of Government, by the introduction of an assembly, is chiefly promoted by the commercial part of the community, in the towns of Quebec and Montreal. The Canadian Habitants, or farmers, who may be stiled the main body of the freeholders of the Country, having little or no education, are unacquainted with the nature of the question, and would, I think, be for, or against it, according to their confidence in the representation of others. The Clergy do not appear to have interfered. But the Canadian gentlemen [i.e. les seigneurs] in general are opposed to the measure...

En ce qui concernait la division de la province et le sort des Loyalistes, Dorchester ne trouva rien de plus positif à recommander que de ne faire aucun changement important: ${ }^{124}$

A division of the province, I am of opinion, is by no means adviseable at present, either for the interest of the new, or the ancient districts, nor do I see an immediate call for other regulations, than such as are involved in the subject of the general jurisprudence of the country. Indeed it appears to me, that the western settlements are as yet unprepared for any organization, superior to that of a county. But ... no time should be lost in appointing a person of fidelity and ability, in the confidence of the loyalists, to superintend, and lead them ... under the title of Lieutenant Governor of the four western districts [Luneburg, Mecklenburg, Nassau and Hesse].

Toutefois, si l'on décidait de créer une nouvelle province "by the wisdom of His Majesty's Councils", il ne voyait aucune raison de priver les Loyalistes du Haut-Canada des avantages d'institutions représentatives.

Devant un si noble détachement, William Wyndam Grenville, cousin germain du premier ministre Pitt, n'eut pas la patience de Lord Sydney et décida de passer à l'action aussitôt après sa nomination au poste de secrétaire d'Etat en juin 1789.125 Il se plongea résolument dans le volumineux dossier canadien avec la détermination de trouver une solution à l'épi-

124 Ibid., II : 959. En prévision d'une division de la province, Dorchester ajouta la description d'un tracé qui servit à la délimitation du Bas et du Haut-Canada. Ibid., II : 960.

$125 \mathrm{~W}$. W. Grenville remplaça Lord Sydney au poste de secrétaire d'Etat. A peine âgé de trente ans et reconnu pour être un homme très actif et un travailleur des plus assidus, le fils de l'ex-premier ministre George Grenville avait déjà acquis une bonne expérience de l'administration comme membre puis vice-président du comité du Conseil privé "for Trade and Plantations". Il s'était rapidement gagné la confiance et l'amitié du premier ministre Pitt qui en vint à le considérer comme son alter ego. 
neux problème constitutionnel - "the most important and extensive of any of the subjects which [he] found in the Office".126 En moins de trois mois, il parvint à mettre au point un projet de nouvelle constitution ainsi qu'il s'en expliqua devant la House of Commons: ${ }^{127}$

As soon as Parliament was prorogued [11 août 1789], he applied himself to the business with the utmost care and consideration. The House would naturally see that it must unavoidably cost him some time to study the subject, to digest his own opinions respecting it, to compare them with the opinions of others of His Majesty's servants... With great application, and unremitting industry, he had been able to accomplish all these objects in less than three months, and had not formed a mere design or outline ... but had actually matured the whole, and reduced it to the shape of a Bill, such as he thought fit to be submitted to the consideration of that House...

Et il s'excusa d'avoir à retarder la présentation de son projet de loi jusqu'à la réception des commentaires de Lord Dorchester "on many points of detail which required local assistance". ${ }^{28}$

Durant les trois mois (d'août à octobre 1789) de préparation de son plan constitutionnel, Grenville consulta les principaux membres du cabinet ministériel dont le prestigieux Grand Chancelier Edward Thurlow - le principal conseiller du roi qui, jadis, à titre de procureur général, avait pris la défense de l'Acte de Québec qu'il jugeait "the only sort of Constitution fit for a Colony". ${ }^{129}$ Tout en reconnaissant que les circonstances avaient changé depuis 1774, Lord Thurlow n'en continuait pas moins à penser que l'entier contrôle du pouvoir législatif par la Couronne offrait la meilleure garantie de dépendance des colonies envers la métropole. En réponse à Grenville qui soutenait que l'absence de modèle constitutionnel métropolitain avait

126 Lettre de W. W. Grenville au roi George III, le 12 octobre 1789. A. Aspinall, ed., The Later Correspondence of George III, 1783-1793 (Cambridge, 1962), 444. 381-382.

127 Discours du 31 mars 1790. The Parliamentary Register, XXVII:

128Ibid.: 382-383. Ces "points mineurs" portaient notamment sur le nombre des représentants et les "qualifications" des électeurs pour les Assemblées législatives du Bas et du Haut-Canada. $1953), 83$.

129 Rapporté par Robert Gore-Browne, Chancelor Thurlow (Londres, 
été l'une des principales causes de la défection des colonies américaines, Thurlow répondit: ${ }^{130}$

\begin{abstract}
You seem to refer it to the want of more ressemblance in their constitution with that of Great Britain. I have been used to think it more referable to the want of connection and dependence in the form of their government upon the mother country... It seems clear, that, if political liberty, which is the governing principle of our constitution, be established in a colony, the sovereignty which, following that principle, must be distributed in certain proportions among the people, will also be established there; and the immediate effect of that will be an habitual independent attention to a separate interest...
\end{abstract}

A défaut de pouvoir maintenir une complète souveraineté de la Couronne, le légiste espérait que la dépendance économique du Canada vis-à-vis de la Grande-Bretagne préserverait au moins la subordination politique: "As a seat of commerce, our present situation in that respect goes a great way to secure it." ${ }^{131}$ Il se montra cependant sceptique quant à la possibilité de garder au gouvernement britannique, comme le pensait Grenville, "a great degree of weight and influence", grâce à l'institution d'un Conseil législatif sur le modèle de la House of Lords. ${ }^{132}$ La formation d'un corps aristocratique héréditaire lui paraissait une solution douteuse: "If placed in hands unequal to it, will be only despised; but if lodged with families of permanent consideration, will grow, as I fear, into an independent interest." ${ }^{133}$ Conscient qu'il ne pouvait arrêter le cours de l'histoire et empêcher l'inévitable séparation des intérêts entre les colonies et leur métropole, le Grand Chancelier accepta le plan de Grenville comme une sorte de fatale nécessité.

Fort de cette acceptation du Grand Chancelier, le secrétaire d'Etat put obtenir du roi l'autorisation de soumettre son projet de loi à l'approbation du Parlement. Mais à l'instar du conseiller de la Couronne, George III exprima son regret de devoir révoquer en partie l'Acte de Québec qu'il croyait sincèrement fondé "on the clearest principles of justice and humanity" dans le but de promouvoir "the happiness of my Canadian subjects" ainsi

130 Lettre de Lord Thurlow à Grenville, [1-10] septembre 1789. Historical MSS. Commission, $13^{\mathrm{e}}$ Rapport, Dropmore Papers (Londres, 1892), I: 504.

131 Ibid.: 505.

132 Lettre de Grenville à Lord Thurlow, 12 septembre 1789. Ibid.: 507. 505 .

133 Lettre de Lord Thurlow à Grenville, [1-10] septembre 1789. Ibid.: 
qu'il l'avait déclaré en donnant sa sanction royale, le 22 juin 1774.134 "I am sorry any change is necessary, déplora le roi, for I am aware to please all concerned is impossible, and that if things could have gone on in its present state for some years, it would have been very desirable"; et avec une touchante marque de considération pour "ses sujets canadiens", il signala que le plan de Grenville "has been drawn up with as much as attention to the interest of the old inhabitants who, by the capitulation, have every degree of right to be first attended to". ${ }^{135}$

Le plan de Grenville reposait sur des considérations économiques, des facteurs politiques et des principes constitutionnels qu'on trouve exposés dans un document de travail intitulé: "Discussion of Petitions and Counter Petitions RE Change of Government in Canada". ${ }^{136}$ Ce mémoire fait ressortir deux préoccupations majeures de l'administration de William Pitt: le développement de la colonisation britannique en Amérique du Nord et le mode de financement de cette colonisation. Ces préoccupations sont assorties à des objectifs politiques visant à maintenir et à préserver le contrôle métropolitain au moyen d'un régime constitutionnel bien assujetti aux prérogatives royales.

Le mémoire de Grenville débute par une analyse des principaux arguments mis de l'avant dans les nombreuses pétitions et contre-pétitions qui, depuis 1783, s'étaient accumulées au secrétariat d'Etat. ${ }^{137}$ Le choix des arguments retenus par Grenville - aussi bien ceux des partisans que des opposants aux réformes constitutionnelles - démontre que la solution proposée était en bonne part dictée par des impératifs d'ordre économique résultant de la perte des anciennes colonies américaines. Malheureusement, cette solution ne produisit pas les résultats espérés parce que ces impératifs économiques commandaient une libéralisation qui allait directement à l'encontre de la réorientation, en 1783, de la politique impériale dans le cadre du "Old Colonial System". Grenville n'était pas sans pressentir les inconvénients de cette

134 Discours du roi George III à la prorogation des Chambres, le 22 juin 1774. The Parliamentary History of England, XVII: 1407-1408.

135 Lettre du roi George III à Grenville, datée de Windsor Palace, le 13 octobre 1789. Historical MSS. Commission, $13^{e}$ Rapport, Dropmore Papers, I : 530 .

136 D'après le titre donné par les archivistes Shortt et Doughty, ed., op. cit. II : 970 à 987 . C'est en date du 26 août 1789 que Grenville envoya son mémoire au Grand Chancelier en sollicitant son opinion. Historical MSS. Commission, 13e Rapport, Dropmore Papers, I : 497.

137 Ces "contre-pétitions" provenaient du groupe seigneurial canadien qui mena une lutte acharnée pour conserver et accroître ses privilèges de classe reconnus par l'Acte de Québec. 
contradiction: "With a view merely to retaining dependence, a legislation residing in the mother country might for a time be the best of all institutions; but that it has so evident a tendency to check and depress the prosperity of the colony, that it might almost be doubted whether such a dependence be worth retaining." 138 Mais le négociateur du futur et premier traité commercial avec les Etats-Unis (le Grenville-Jay Treaty de 1794) demeurait trop captif de la mentalité féodale qui caractérisait l'élite aristocratique anglaise pour pouvoir se libérer des liens idéologiques qui le rattachaient au système protectionniste du First British Empire.

Dans son analyse des arguments pour et contre les réformes constitutionnelles, le ministre insista sur deux faits déterminants dans l'ordre de ses préoccupations. D'abord, il constata que le British North America était destiné à se peupler presque exclusivement de colons britanniques: ${ }^{139}$

From the great, \& continued influx of New Settlers, \& from the resources of the country itself, there is every reason to believe, that the wealth \& population of the Province are rapidly increasing; but the increase has hitherto been almost entirely confined, \& will probably continue to be so, to the British \& American Settlers.

Dans cette perspective, il lui apparut indispensable de donner suite aux promesses de la Proclamation royale de 1763 ; comment retarder plus longtemps la réalisation de ces promesses alors que le nombre des Loyalistes s'accroissait d'année en année? En étant soumis aux lois, us et coutumes de la majorité canadienne-française, ces Loyalistes ne pourraient bénéficier de leurs droits et privilèges; puisqu'ils formaient déjà la plus grande proportion de colons britanniques au Canada, pourquoi ne pas leur offrir les mêmes avantages des "libertés anglaises" qu'à leurs compatriotes de la Nouvelle-Ecosse et du Nouveau-Brunswick ? Il fallait aussi soulager la Grande-Bretagne du lourd fardeau des dépenses que lui occasionnait le soutien de la colonie et qui s'élevaient à près de $£ 100,000$ annuellement sans compter la solde des troupes. ${ }^{140}$ Depuis 1778 , le Parlement britannique avait officiellement renoncé à son droit d'imposer aux colonies des taxes pour des dépenses relevant de l'administration locale

138 Lettre de Grenville à Lord Thurlow, le 12 septembre 1789. Historical MSS. Commission, 13e Rapport, Dropmore Papers, I: 507.

139 Shortt et Doughty, ed., op. cit., II : 971-972.

$140 \mathrm{Au}$ total, pour l'année 1788, il en avait coûté à la Trésorerie £152,583. Chiffre donné par Vincent T. Harlow, op. cit., II: 754 . 
et pour des fins de défense générale $;^{141}$ par l'établissement d'une Chambre d'Assemblée, on remettait ce pouvoir de taxation aux élus du peuple. Ce partage du fardeau fiscal était devenu si urgent que l'historien Harlow a pu écrire: "the financial case for running the political risk of establishing a predominantly French Assembly in Quebec was strong - almost to the point of compulsion". ${ }^{142}$

Parmi les objections formulées par les seigneurs canadiens s'opposant à l'établissement d'une Chambre d'Assemblée, Grenville en releva trois principales: a) la crainte des taxes; b) la crainte d'une prépondérance des "Old British Subjects" à l'Assemblée législative; $;^{143}$ c) la crainte des lois anglaises. A la première objection - crainte des taxes que les seigneurs avaient utilisée pour alerter et alarmer leurs censitaires contre toute réforme constitutionnelle - le ministre opposa que les Canadiens ne pouvaient choisir d'en être exemptés; lorsqu'ils auront compris, ils préféreront être taxés par leurs propres représentants plutôt que par des conseillers législatifs nommés par la Couronne. Aux deux dernières objections, Grenville trouva réponse par la formation de deux législatures provinciales: ${ }^{144}$

If these two bodies, \& Classes of Men, differing in their prejudices, \& perhaps, in their interests, were to be consolidated into one legislative body, dissensions, \& animosities might too probably prevail; \& the success of either party might, in fact, be injurious to the other. It should seem therefore, that the natural remedy, for this, would be, the separation of the province into two districts, having distinct Legislatures, in which, the separate interests of the old, \& new Subjects might preponderate, according to the respective proportion of population, \& of wealth.

En préparant son projet de nouvelle constitution, Grenville tint compte des remèdes jadis prescrits par William Knox et Sir Francis Bernard. ${ }^{145}$ Convaincu que la déficience constitutionnelle des anciennes colonies américaines avait été l'une des principales causes de leur défection, il crut prévenir ce danger par la formation d'un corps législatif indépendant "to operate as a check, both on the misconduct of Governors, \& on the democrati-

141 Cette initiative avait été prise dans l'espoir de réconcilier à la métropole les colonies américaines révoltées.

142 Vincent T. Harlow, op. cit., II: 755 .

143 En fait, les seigneurs craignaient autant, sinon plus, la prépondérance de leurs propres censitaires à l'Assemblée législative.

144 Shortt et Doughty, ed., op. cit., II: 976. C'est nous qui soulignons natural remedy.

145 Tels qu'exposés au début de cette troisième partie. 
cal Spirit, which prevailed in the [American] Assemblies". ${ }^{146} \mathrm{Ce}$ corps législatif indépendant devait remplir les fonctions de la House of Lords qui formait "the Aristocratical part of our Constitution" et constituer dans les futures provinces du Bas et du Haut-Canada "a respectable Aristocracy, as a support, \& safeguard of the Monarchy". Afin de rendre encore plus respectables les détenteurs de ce pouvoir intermédiaire dans une "mixed and balanced constitution", on leur attribuerait des marques d'honneur ou de distinction avec privilèges héréditaires. ${ }^{147}$

Si dans les treize colonies américaines, la partie aristocratique de la constitution britannique avait fait défaut, la partie monarchique représentée par le gouverneur laissait également à désirer: ${ }^{148}$

The nature of the Situation allotted to the Governors in America, the limited extent of their Authority, the dependence, in which they frequently found themselves, on the Colonies even for their own Support, \& Maintenance, the little consequence annexed to their Station, \&, sometimes, the character, \& rank of the persons sent there, were but ill adapted to remedy the defect arising from the absence of the Sovereign.

Comme le gouverneur ne pouvait, à l'instar du roi, dispenser des honneurs et des émoluments "to animate the exertions of individuals, \& to secure their attachment to the existing form of Government", Grenville projeta de rehausser le prestige et l'influence de l'autorité exécutive en consolidant les gouvernements provinciaux sous une seule personne qui réunirait les pouvoirs civil et militaire. ${ }^{149}$

Dès qu'il eut obtenu l'autorisation du roi de soumettre son projet de loi au Parlement, Grenville s'empressa d'en faire part au gouverneur Dorchester. Le moment lui parut des plus propices alors que la situation en France "gives Us little to fear... The opportunity is therefore most favourable for the adoption of such measures as may tend to consolidate Our strength, and increase our resources". ${ }^{150}$ Il invita le gouverneur à collaborer à la réalisation de ce plan tout en le prévenant que la décision de

146 Shortt et Doughty, ed., op. cit., II : 978.

147 Ibid.: 978-979.

148 Ibid.: 984.

149 Ibid.: 985-986.

150 Lettre "privée et secrète" de Grenville à Dorchester, le 20 octobre 1789. Ibid.: 970. Dorchester reçut le "First Draught of Constitutional Bill" en janvier 1790. Voir ce texte dans Ibid.: 992 à 1002. 
séparer le Bas du Haut-Canada était irrévocable. Il lui exposa le bien-fondé de cette division: ${ }^{151}$

... a considerable degree of attention is due to the prejudices and habits of the French Inhabitants who compose so large a proportion of the community, and every degree of caution should be used to continue to them the enjoyment of those civil and religious Rights which were secured to them by the Capitulation of the Province, or have since been granted by the liberal and enlightened spirit of the British Government ... Every consideration of policy seemed to render it desirable that the great preponderance possessed in the Upper Districts by the King's ancient Subjects, and in the Lower by the French Canadians should have their effect and operation in separate Legislatures; rather than that these two bodies of People should be blended together in the first formation of the new Constitution, and before sufficient time has been allowed for the removal of ancient prejudices, by the habit of obedience to the same Government, and by the sense of a common interest.

Les directives précises du secrétaire d'Etat ne laissèrent pas grande latitude à Lord Dorchester pour faire amender le projet de loi. ${ }^{152}$ Les longs délais dans l'échange de correspondance avec le gouverneur et les dernières mises au point obligèrent l'administration gouvernementale à reporter au début de l'année 1791 la présentation officielle du projet d'Acte constitutionnel. Ne pouvant plus compter sur la présence à la House of Commons de son cousin devenu Lord Grenville, ${ }^{153}$ le premier ministre Pitt affronta seul les critiques de l'opposition après la première lecture du "Canada Bill", le 4 mars.

Le plaidoyer qu'Adam Lymburner, le délégué de la bourgeoisie coloniale, avait présenté devant le comité de la Chambre, le 23 mars, procura des munitions à l'opposition parlementaire pour attaquer la politique gouvernementale. Le célèbre orateur de la Chambre, Charles James Fox, brillant franc-tireur de l'opposition, trouva dans le projet de la nouvelle constitution canadienne ample matière à harceler le ministère. Ce chef de l'aile réformiste du parti Whig était connu pour ses sympathies républicaines et il profita de ce débat pour se faire du capital politique.

151 Deuxième lettre de Grenville à Dorchester, le 20 octobre 1789. Ibid.: 988 .

152 Pour les précisions, corrections et amendements apportés par le gouverneur, voir le "Second Draught of Constitutional Bill", Ibid.: 1006 à 1016. bre 1790 .

W. W. Grenville avait été promu à la House of Lords, en novem- 
Les historiens du Canada anglais n'ont retenu des critiques de Charles James Fox que sa sortie contre la division de la province de Québec: "The most desirable circumstance was, that the French and English inhabitants should unite and coalesce, as it were, into one body, and that the different distinctions of the people might be extinguished for ever." ${ }^{154}$ Ce serait se méprendre que de voir dans son argumentation l'expression d'une politique définie d'assimilation alors que le but recherché par ce chef d'opposition était de prendre en défaut l'administration de William Pitt. D'ailleurs les seuls amendements à la loi que Fox parvint à faire adopter par ses nombreuses critiques eurent précisément pour effet de favoriser la majorité canadiennefrançaise du Bas-Canada: l'augmentation du nombre des députés de trente à cinquante, la réduction des "qualifications" des électeurs et le renouvellement de l'Assemblée à tous les quatre ans au lieu de sept.

Ce fut sur un ton à la fois ferme et sans agressivité que le premier ministre Pitt répondit aux objections soulevées par Fox contre la séparation du Bas et du Haut-Canada: ${ }^{155}$

As to the division of the province, it was, in a great measure, the fundamental part of the bill; and he had no scruple to declare that he considered it as the most material and essential part of it. He agreed with the honourable gentleman, in thinking it extremely desirable that the inhabitants of Canada should be united, and led universally to prefer the English constitution and the English laws. Dividing the province, he considered to be the most likely means to effect this purpose, since by so doing, the French subjects would be sensible that the British Government had no intention of forcing the English laws upon them, and therefore they would, with more facility, look at the operation and effect of those laws, compare them with the operation and effect of their own, and probably in time adopt them from conviction...

Que William Pitt ait pu souhaiter voir les Canadiens adopter les lois anglaises, on ne saurait en douter, mais de là à prétendre que l'anglicisation des Canadiens constituait l'un des principaux objectifs du plan de Grenville, ${ }^{158}$ c'est enlever tout sens à la politique coloniale du gouvernement métropolitain. On se doit de distinguer entre les arguments qui servent de justification

154 Discours du 8 avril 1791. The Parliamentary Register, XXIX: 73. 155 Ibid.: 76-77.

156 Ainsi que l'affirme l'historien Gerald M. Craig: "Both men [Fox et Pitt] agreed that Anglicizing the French should be a main object of legislation". Upper Canada: The Formative Years. 1784-1841 (Toronto, 1963), 17. 
à une législation et les raisons qui en constituent le fondement. Si l'on examine les raisons fondamentales qui ont motivé la décision ministérielle de créer deux gouvernements provinciaux distincts au Canada, on n'y trouve aucun dessein ni aucune volonté de traduire en acte législatif une quelconque politique d'assimilation. Le premier ministre expliqua clairement les préoccupations politiques de son administration au sujet de cette division de la province de Québec: ${ }^{157}$

It appeared to His Majesty's Ministers ... that there was no probability of reconciling the jarring interests and opposing views of the inhabitants, but by giving them two Legislatures... It seemed to His Majesty's servants the most desirable thing, if they could not give satisfaction to all descriptions of men, to divide the province, and to contrive that one division should consist, as much as possible, of those who were well inclined towards the English laws, and that the other part should consist of a decided preponderancy of the ancient inhabitants, who were attached to the French laws...

Reconnaissant qu'il était pratiquement impossible de donner satisfaction "to all descriptions of men", c'est-à-dire à tous les différents groupes composant la population coloniale, il précisa les raisons qui avaient obligé le gouvernement métropolitain à sacrifier les intérêts de la minorité protestante du Bas-Canada :158

It was perfectly true... that in Lower Canada there still remained a certain number of English subjects, but these would hold a much smaller proportion than if there was one form of Government for every part of the province. It was in Upper Canada particularly that they were to expect a great addition of English inhabitants. The consequence was, that if it was not divided from the rest, the Canadians forming a majority of five to one, the grievance would be every year increasing in proportion as the population increased.

Ces explications furent si bien interprétées par Edmund Burke, le célèbre auteur des Reflections on the Revolution in France, qu'il déclara en donnant son appui au plan de Grenville: "An attempt to join people dissimilar in law, language, and manners, appeared to him highly absurd... Let the Canadians have a constitution formed upon the principles of Canadians, and Englishmen upon the principles of Englishmen." 159

157 Discours du 11 mai 1791. The Parliamentary Register, XXIX: 379-380.

158 Ibid.: 380 .

150 Ibid.: 381. 
Lorsque le comité de la Chambre passa en revue les divers articles du projet de loi, les aspects proprement constitutionnels retinrent l'attention et ce furent les modalités d'application de la constitution britannique au Canada qui suscitèrent un échange d'opinions entre le chef du gouvernement William Pitt et son principal adversaire en Chambre, Charles James Fox. Malgré leur différente allégeance aux deux grands partis Whig et Tory, ces deux illustres représentants de la société aristocratique anglaise du dix-huitième siècle vouaient à la forme politique du gouvernement britannique une commune admiration et vénération. Au-delà de leurs divergentes options politiques, ils partageaient la même vision de l'ordre politico-social que sanctionnait la constitution britannique. Leurs plaidoyers respectifs sur ses modalités d'application au Canada constituent la meilleure défense et illustration de cette mentalité féodale qui donne tout son sens au "Lord Grenville's Act".

Charles James Fox fit porter l'essentiel de sa critique sur le mode de formation du Conseil législatif. Au lieu de faire de ses membres des instruments serviles de la Couronne, il proposa de constituer un véritable corps législatif "indépendant du gouverneur et du peuple" au moyen de l'élection des conseillers par la seule classe des plus riches propriétaires terriens et non par scrutin populaire comme c'était le cas pour les représentants de la Chambre d'Assemblée: 180

By this means they would have a real aristocracy chosen by persons of property from among persons of the highest property, and would thence necessarily possess that weight, influence, and independency, from which alone could be derived a power of guarding against any innovations that might be made, either by the people on the one part, or the Crown on the other.

Fox s'efforça de rassurer les membres de la Chambre: il n'entendait nullement par cette réforme remettre en question le partage des pouvoirs tel qu'établi par la constitution britannique mais, au contraire, c'était par considération pour le noble corps de la House of Lords qu'il s'objectait à reconstituer en Amérique du Nord "a servile imitation of our aristocracy... a very inadequate substitute - a semblance but not a substance". ${ }^{161}$

En rejetant le projet de réforme de Fox, le premier ministre Pitt profita de l'occasion qui lui était offerte pour faire l'éloge de la Constitution britannique: ${ }^{162}$

160 Ibid.: 390-391.

161 Ibid.: 390-391.

162 Ibid.: 393-394. 


\begin{abstract}
Aristocracy was ... the true poise, as the right honourable gentleman had emphatically stated it, of the constitution; it was the essential link that held the branches together, and gave stability and strength to the whole; aristocracy reflected lustre on the Crown, and lent support and effect to the democracy, while the democracy gave vigour and energy to both and the sovereignty crowned the constitution with authority and dignity... Our aristocracy was not merely respectable on account of its property, though that undoubtedly was no small consideration in the scale of its respectability; but it was essentially respectable for its hereditary distinctions flowing from the Crown, as the fountain of honour... He should lament, therefore, to create an aristocracy by a selection from property alone, or by making it elective, as in either case it would render the poise nearer to the people than it was to the Crown in the British constitution.
\end{abstract}

Tout en admettant qu'on ne pouvait former une nouvelle noblesse coloniale jouissant de tout le respect qu'inspirait la House of Lords dont les membres s'honoraient d'une haute lignée héréditaire remontant à l'Antiquité, il n'en croyait pas moins possible de lui procurer "the same degree of respect as had accompanied the origin of our nobility, and succeeding ages would bestow all the rest". D'ailleurs, n'y avait-il pas déjà dans les habitudes, les coutumes et les usages des Canadiens français "something that peculiarly fitted it for the reception of hereditary honours"? Certains seigneurs ne possédaient-ils pas à un degré suffisant "property and respect" pour espérer que la prospérité de la colonie qui suivrait la mise en application de la nouvelle constitution "would make them hold a fair weight in that constitution, and imperceptibly clothe them with that respect and influence that ought to belong to the aristocratical branch of a free Government" ? Ainsi, en était-il fermement convaincu, il en résulterait un resserrement de liens entre la colonie et la mère patrie. ${ }^{163}$

Les débats parlementaires s'achevèrent sur ces hommages rendus à la Couronne et à l'aristocratie. Alors qu'en France était lancé à l'assaut de la monarchie et des privilèges de classe nobiliaire le mouvement révolutionnaire, dans cette auguste enceinte du Parlement britannique, continuait à prédominer le système de valeurs propre au monde rural du dix-huitième siècle. Grenville et Pitt incarnaient l'idéologie d'une société aristocratique où la propriété foncière constituait le fon-

163 Ibid.: 394-395. 
dement du pouvoir politique; Durham et Russell, cinquante ans plus tard, représenteront l'idéologie de l'ère de la conquête des marchés mondiaux par la bourgeoisie industrielle du dix-neuvième siècle. Forts de leur importance comme majorité de propriétaires terriens, les Canadiens français profitèrent, au cours des trente années qui suivirent la cession du Canada à l'Angleterre, de la conception féodale de l'ordre politico-social des dirigeants de l'empire. L'avenir n'en devait pas moins appartenir aux valeurs bourgeoises de la minorité protestante même si, en 1791, on la sacrifia "on the altar of French Canada". 